\title{
LØNSYSTEMER I KRISEN
}

\author{
Allan Andreassen, \\ Soren Kerndrup og \\ Tyge Kjær
}

Diskussionen af arbejderklassens situation under krisen kredser med god grund omkring kampen mod indkomstpolitikken på den ene side og styrkelsen af arbejderklassens faglige organisationer på den anden side.

Med denne artikel $\emptyset$ nsker vi at tilføre diskussionerne nogle elementer, som vi mener bliver overset: nemlig betydningen af kapitalismens objektive tvangslove. Arbejderklassen står ikke kun overfor en kamp mod statslig indkomstpolitik og arbejdsgiverpolitik. Den har hele den kapitalistiske produktionsmåde, dens lovmæssigheder og deres virkemåder imod sig. Selv den mest effektive fagforeningspolitik vil komme til kort overfor kapitalismens tvangslove. "Da det må erkendes ...", hedder det i fagforeningsmanifestet fra 1886, ${ }^{1}$ )"at den privatkapitalistiske Produktionsmåde stadig vil vare en Hindring for at tilvejebringe Lykke og Tilfredshed i Samfundet, udtaler Kongressen sin anerkendelse af de socialistiske Principper".

Denne erkendelse må fastholdes; udviklingen har intet ændret siden 1886; kapitalismen er den egentlige hindring og byrde for arbejderklassen, og ikke den ene eller den anden politik isoleret betragtet.

Med artiklen forsøger vi at påvise de objektive ændringer i arbejderklassens kampbetingelser, som den kapitalistiske krise påtvinger arbejderklassen. Arbejderklassens aktuelle styrke hentes ikke ud af den blå luft, men hænger ubønhørligt sammen med kapitalismens direkte virkninger på arbejderklassen og dens organisationsmuligheder.

For arbejderklassen er den umiddelbart vigtigste virkning af krisen en faldende beskæftigelse. Den får reservearméen til at vokse og dermed forøges også trykket på arbejdslønnen gennem konkurrencen fra arbejderklassens ubeskæftigede del.

Reservearméens størrelse, sammensætning, og hvor bevægelig den er, udgør derfor det materielle grundlag for arbejderklassens styrke og svaghed, når det drejer sig om at forsvare arbejds- og levevilkårene.

1. Kongresbeslutning fra 27.-29. august 1886, punkt lc (vores fremh.); udsendt af "Udvalget for de samvirkende Fagforeningers Fællesvirksomhed" (centralorganet), november 1886. Her udtrykkes i stor udstrækning de samme synspunkter, som Marx gjorde gældende i Første Internationale. 
Hermed afvises ikke betydningen af f.eks. den statslige indkomstpolitik og skattepolitik; eller LO og DA's løntilbageholdelsespolitik ved de generelle overenskomster; Arbejdsgiverforeningens præmiering af arbejdsgivere, som har vist sig modstandsdygtige overfor "lønhamstringen", og deres samtidige afstraffelse af arbejdsgivere, som ikke står imod; eller kriminalisering og retsforfølgelse af strejker og arbejdspladsaktioner. Men vores hovedsynspunkt er, at disse magtforanstaltninger ikke kunne gennemføres og få reelle virkninger, hvis arbejderklassens styrkepositioner ikke var blevet svækket gennem den voksende reservearmé som en følge af krisen.

Sagen kunne betragtes omvendt: de nævnte foranstaltninger (og flere til) kan ses som et forsøg på at fremskynde, formidle og almengфre den voksende reservearmés løntrykkende virkninger; deres succes vil afhænge af, i hvor stor udstrækning reservearméens løntrykkende virkninger er almene eller dominerende for hele arbejderklassen, hvor desorganiserende og opsplittende reservearméen virker; og vil således afhænge af, hvilken modstand arbejderklassen dagligt på arbejdspladserne er i stand til at yde under den voksende reservearmés svækkelse af arbejderklassens styrkepositioner. De forskellige politikker kan derfor opfattes som en subjektiv sammenfatning af kapitalismens objektive tvangslove under krisen. Men uanset om denne sammenfatning finder sted eller ej, f.eks. i form af statslig indkomstpolitik, så vil de objektive tvangslove alligevel gøre sig gældende overfor arbejderklassen.

Vi skal behandle disse tvangsloves virkninger eksemplarisk med udgangs-

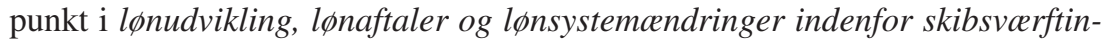
dustrien og her belyse den rolle, som reservearméen spiller for værftsarbejdernes forsvar for arbejds- og levevilkårene.

I artiklen går vi frem på følgende måde: først behandler vi arbejdslønnens udvikling generelt (afsnit 1); så behandler vi akkordlønsystemers virkning på arbejdslønnen (afsnit 2). Dernæst behandler vi den konkrete udvikling i værftsindustrien (afsnit 3).

\section{Reservearméen og dens virkninger}

Der er ikke en direkte sammenhæng mellem den samlede industrielle reservearmé og udviklingen af arbejdslønnen på en bestemt fabrik. Det hænger sammen med to forskellige former for ændringer i arbejdslønnen. Den ene form for ændringer angår arbejdslønnens generelle og mere langsigtede udvikling, 
mens den anden form angår svingninger i arbejdslønnen på grund af lokale svingninger af arbejdsmarkedet i relation til en bestemt branche. Vi skal belyse forskellen mellem disse to former i det efterfølgende.

1. Generelle andringer $i$ arbejdslфnnen hænger sammen med kapitalakkumulationens historiske forløb, og er et spørgsmål om forholdet mellem arbejderklassen og totalkapitalen. Den er stort set udelukkende reguleret ved den industrielle reservearmés forøgelse eller formindskelse, som er en følge af skiften i den industrielle cyklus. Det afgørende er arbejdslønnens størrelse er omskifteligheden i størrelsesforholdet mellem den aktive industrielle armé og den industrielle reservearmé. ${ }^{2}$ ) Vi skal se på, hvordan denne omskiftelighed veksler med kapitalakkumulationen.

Vokser den organiske sammensætning gennem udvidelse af maskindriften i produktionen og vokser arbejdsproduktiviteten gennem intensiveringer, dannes der en variabel overskudskapital, som er overflødig i forhold til den allerede anlagte kapital, og som fører til frisættelse af arbejdskraft og dermed forøgelse af den industrielle reservearmé. Hvis profitproduktionsbetingelserne er gunstige vil den frisatte arbejdskraft straks opsuges påny gennem en ekspansion af totalkapitalen. "På denne måde bliver arbejderne hele tiden snart jaget ud af fabrikkerne, snart trukket ind i dem, slynget frem og tilbage og dette mens der hele tiden sker ændringer i køn, alder, faglige færdigheder hos dem, der ansættes." ${ }^{3}$ )

Det er faktisk situationen i 1960'erne og begyndelsen af 1970'erne. Den intensive kapitalakkumulation fører til både frisættelse af arbejdskraft gennem udvidelse af maskindriften i produktionsprocessen og til opsugning af arbejdskraft gennem kapitalens kvantitative ekspansion. Det har da også til resultat, at den industrielle beskæftigelse stort set er konstant i perioden, selvom disse konstante tal rummer store svingninger de enkelte brancher imellem, og i køn, alder og faglig sammensætning af de industrielt beskæftigede.

Men situationen ændres ved krisegennembruddet i 1974/75. Den industrielle reservearmé begynder at vokse yderligere. Det hænger sammen med to forhold: for det første indskrænkninger i den produktivt fungerende kapital gennem helt eller delvise braklægninger, og for det andet fortsat - og iøvrigt stigende - frisættelse af variabel kapital uden (som tidligere) modsvarende opsugning af den frisatte arbejdskraft. Den voksende og i de efterfølgende år kraftigt stigende

2. Gennem kapitalismens virkninger på arbejderklassen spaltes den hele tiden op i to dele: den aktive industrielle armé (de beskæftigede) og den industrielle reservearmé (de ubeskæftigede). Reservearméen er sammensat af en række forskellige dele; den vigtigste skelnen er, om den er flydende eller ej, d.v.s. om den omgående kan bringes ind på fabrikkerne eller ej. Reservearméens aktuelle sammensætning er behandlet i Bo Elling Nielsen: Den statslige arbejdsmarkedspolitik i krisen; KURASJE 18, 1978, s. 103-135.

3. K. Marx: Kapitalen, København 1971, 1:3, s. 651. 
reservearmé danner det egentlige grundlag for den generelle udvikling i arbejdslønnen i form af stigende løntryk.

Nogle tal kan illustrere forholdet mellem den teknologisk betingede frisattelse på grund af stigninger i kapitalens organiske sammensætning og opsugning på grund af kapitalens kvantitative vækst. ${ }^{4}$

I 1973 blev der frisat knap 26.000 arbejdere og funktionærer i industrien gennem teknologisk udvikling. Nettobeskæftigelsen voksede med 13.500 mand $\mathrm{i}$ industrien; det betyder, at der blev opsuget knap 40.000 mand gennem kapitalens kvantitative vækst. Krisen bryder igennem i slutningen af året, så 1973 er - året taget som helhed - ét af de sidste ekspansive år i den intensive akkumulationsfase.

I 1974 frisattes ca. 48.000 mand i industrien gennem iøvrigt historiens største investeringer i driftsmidler. Den samlede beskæftigelse faldt med ca. 13.000 mand. Modsvarende hertil fandt der en opsugning sted på mindst ca. 35.000 mand (mindst, fordi der også er sket en opsugning af den arbejdskraft, som er frisat gennem braklægninger i dette år; det er vi imidlertid ikke i stand til at beregne størrelsen af).

I 1975 frisattes ca. 34.000 mand i industrien gennem den teknologiske udvikling; den samlede beskæftigelse faldt med ca. 38.000 mand. I modsætning til 1974 sker der således ikke en nettoopsuging af den frisatte arbejdskraft, men beskæftigelsen falder yderligere med 4.000 mand på grund af produktionsindskrænkninger. 1975 er da også det år, hvor reservearméen vokser kraftigst (se også beskæftigelsesudviklingen i figur 1).

I 1976 frisattes der ingen arbejdskraft gennem teknologisk udvikling; det intensive akkumulationsmønster er ophørt. Nettobeskæftigelsen voksede med 2.400 mand i industrien, som især må tilskrives midlertidig produktiv inddragelse af kapital, som har været braklagt i de foregående år. ${ }^{5}$

Efterhånden som den intensive kapitalakkumulations virkninger sætter sig igennem ved den fuldstændige forvandling af hele den konstante kapital viser virkningerne sig: der frisættes mere arbejdskraft end der opsuges, fordi den variable kapital i stigende omfang udgør en så faldende andel af totalkapitalen, at den variable kapitals absolutte størrelse begynder at falde for alvor. I perioden

4. De teknologiske betingede frisættelser beregnes med udgangspunkt i den relative formindskelse af den variable kapital. Den derved relativ frigjorte variable kapital omsættes dernæst i antal arbejdere på basis af industriens gennemsnitslønninger; der er derfor tale om cirka-tal. Beregningsmetoden er behandlet i Tyge Kjar: Den intensive kapitalakkumulationsperiodes ændringer i økonomiseringsgrundlaget og dens betydning for arbejdskraften; TEK/SAM-GRUNDKURSUS, 1978 Bd. III, s. $91 \mathrm{ff}$.

5. I 1976 vokser både den variable kapital (som nævnt) og den flydende konstante kapital (dvs. materialeforbrug), mens fixkapitalens størrelse er uændret. Det indicerer derfor inddragelse af tidligere braklagt kapital, d.v.s. stigende kapacitetsudnyttelse. 
1960-76 (incl.) steg den konstante kapital knap med 117\%, mens den variable kapital faldt med knap 10\%. ${ }^{6}$

Det er således ikke en historisk tilfældighed, at den industrielle reservearmé vokser frem; den er et logisk resultat af den intensive kapitalakkumulation. Det er ikke en voksende arbejderbefolkning, som ikke kan finde beskæftigelse, men omvendt: det er den intensive kapitalakkumulation, som har produceret den voksende overskudsbefolkning - den industrielle reservearmé.

Det betyder også, at arbejdslønnens generelle bevægelser ikke er bestemt af det absolutte antal arbejdere og efterspørgsel på arbejdskraft. Kapitalen g $\phi r$ sig uafhaengig af det absolutte antal arbejdere og af den aktuelle efterspørgsel på arbejdskraft ved at producere en industriel reservearmé gennem den intensive kapitalakkumulation.

Arbejdslønnens generelle udvikling er derfor bestemt af akkumulationens virkninger på arbejderklassen. Får akkumulationen arbejderklassens reserver til at vokse, så forøges dermed det tryk, som den ubeskæftigede del udøver gennem konkurrencen overfor de beskæftigede.

I kraft af den intensive kapitalakkumulations virkninger bliver den generelle problemstilling for arbejderklassen at forsvare den eksisterende arbejdsløn gennem at begrænse den omtalte konkurrences virkninger.

2. Svingninger $i$ arbejdslфnnen. Årsagen til svingninger i arbejdslønnen er af mere branchemæssig og lokal art. Svingningerne finder sted indenfor de rammer, som bestemmer de generelle ændringer i arbejdslønnen. Vi skal vise hvorfor.

Hvis profitproduktionsbetingelserne i forhold til tidligere udvikler sig særligt gunstigt indenfor en branche, og hvis tillægskapital søger derhen, vil efterspørgsel på arbejdskraft stige, uanset om tillægskapitalen anlægges med en betydelig større organisk sammensætning end branchens allerede anlagte kapital. Den stigende efterspørgsel på arbejdskraft får arbejdslønnen til at stige. Den højere arbejdsløn vil tiltrække flere arbejdere, indtil branchen er mættet med arbejdskraft og lønnen påny vil falde, svarende til det tidligere løngennemsnit eller endnu lavere, afhængig af hvor mange arbejdere branchen tiltrak (som må ses i sammenhæng med reservearméens bevægelighed ${ }^{7}$ ), og af om der løbende sker frisættelse gennem en fortsat akkumulation.

Lønnens svingninger er altså på den ene side bestemt af den absolutte størrelse af den del af arbejderklassen, som er beskæftiget i den pågældende branche

6. Jvf. Allan Andreassen og Tyge Kjar: Industriel udvikling. Statistisk oversigt over kapitalrentabilitet, m.v. TEK/SAM-RUC, 1978, bd. I.

7. Forskydninger mellem udbud og efterspørgsel på arbejdskraft bestemmer svingningerne på det lokale arbejdsmarked, men kun indenfor visse rammer. Er en stigende efterspørgsel permanent, vil den nationale industrielle reservearmé på et eller andet tidspunkt sætte sig i bevægelse, afhængig af hvor flydende den industrielle resevearmé er. 
og af de bevægelser, som fremkommer gennem tilgang og afgang af arbejdere til branchen, og på den anden side bestemt af den pågældende branches efterspørgsel på arbejdskraft.

Netop fordi tendentielle højere arbejderlønninger i en branche eller på en enkelt fabrik vil udlignes gennem tilstrømning af ubeskæftiget arbejdskraft, viser det, at svingninger i arbejdslønnen er underordnet de bestemmelser, som gælder for arbejdslønnen generelle bevægelser. Det kan siges på en anden måde: svingninger i arbejdslønnen er bestemt gennem udbud/efterspørgsel på arbejdskraft, men selve den lønstørrelse, som arbejdslønnen svinger omkring, er bestemt af den industrielle reservearmés størrelse. ${ }^{8}$

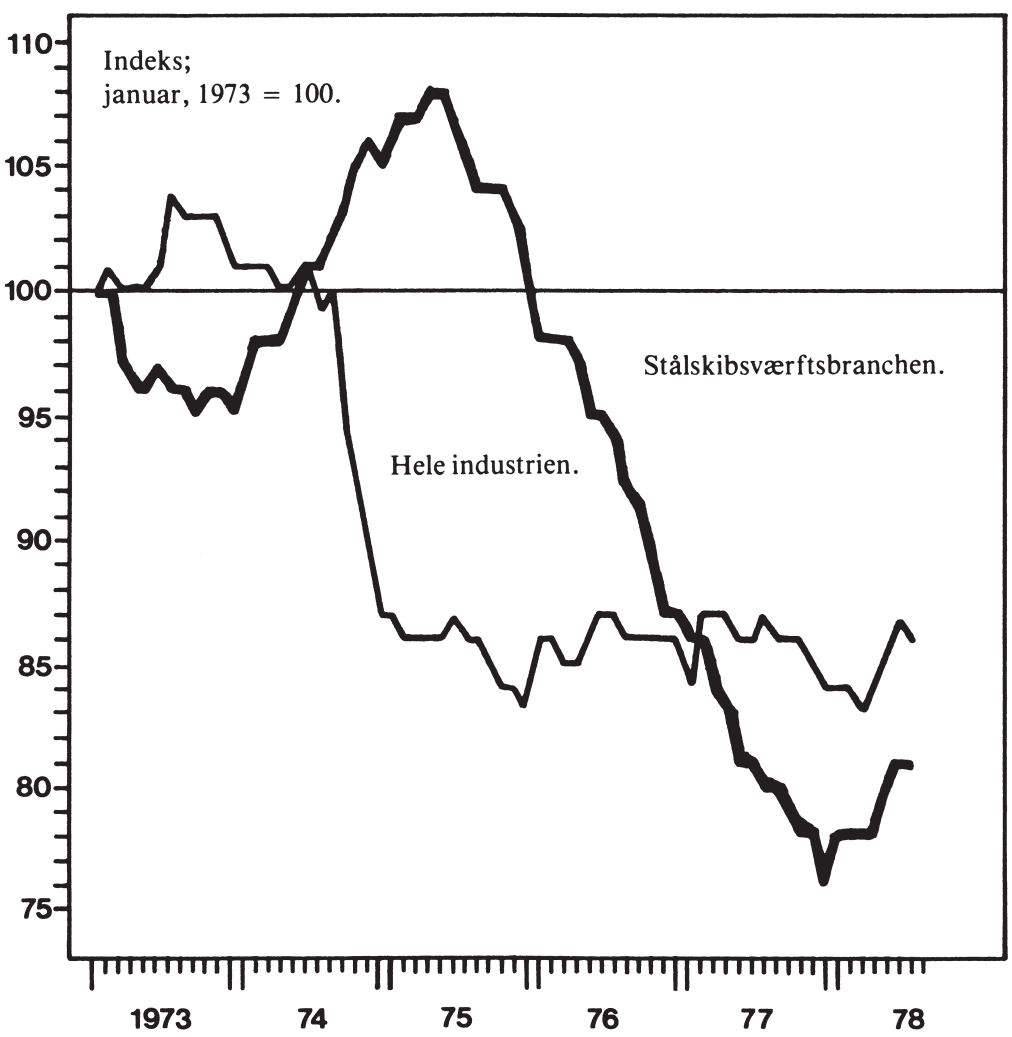

Figur 1. Antal af beskæftigede arbejdere i hele industrien. Indeks: januar $1973=100$. Fra Statistiske Efterretninger, diverse årgange og numre.

8. Vi har ikke glemt værdibestemmelserne. Arbejdskraftens værdi er den gennemsnitlige samfundsmæssige arbejdstid, som under de historisk givne forhold anvendes til reproduktion af arbejdskraften. Arbejdskraftens værdi er imidlertid ikke en objektiv, historisk urørlig størrelse; den er bestemt af 
Med et eksempel skal vi vise sammenhængen mellem lokale ændringer i arbejdsmarkedet og svingninger i arbejdslønnen i forhold til arbejdslønnens generelle udvikling.

For værftsindustrien $\mathrm{g} \varnothing \mathrm{r}$ det særlige forhold sig gældende, at mens den samlede beskæftigelse i industrien begynder at falde i 1973 og falder meget kraftigt i 1974-75, så stiger beskæftigelsen i værftsindustrien fra begyndelsen af 1974 til midten af 1975 (se figur 1). ${ }^{9}$ Frederikshavn Varft er ét af de værfter, som i perioden har den største stigning i beskæftigelsen. Der inve-

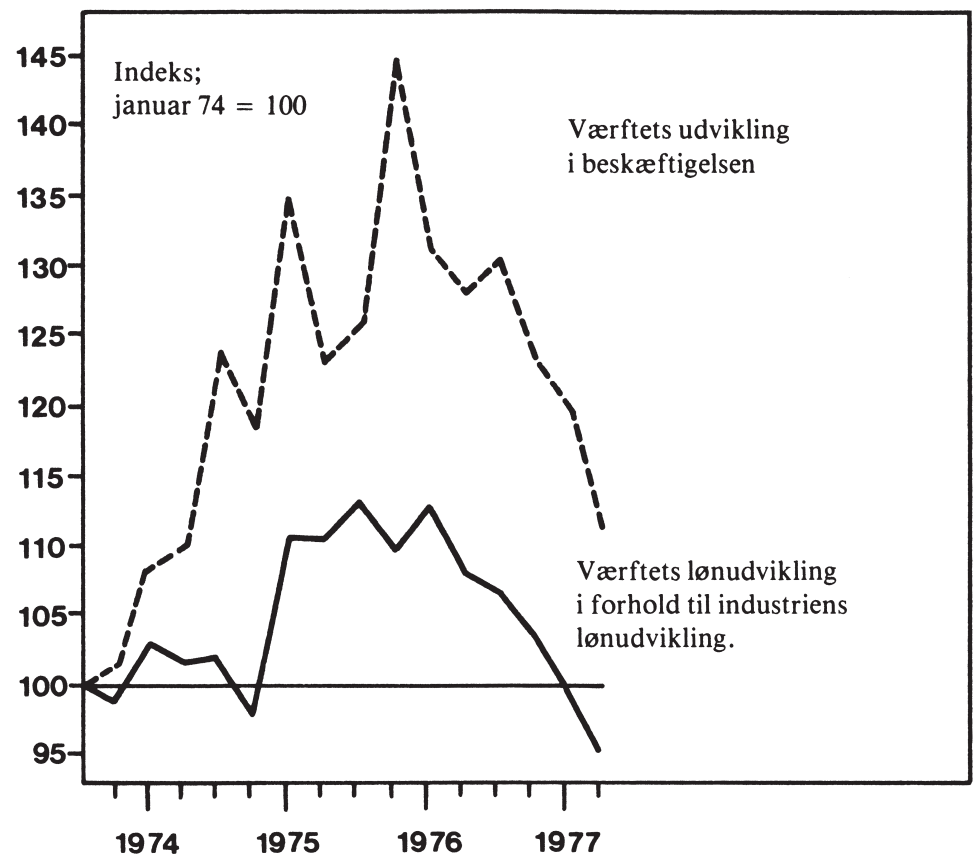

Figur 2. Udviklingen i beskæftigelsen på Frederikshavns Værft, samt værftets arbejderlønninger i procenter af hele industriens arbejderlønninger i perioden 1974-77. Kilde: diverse årgange af Dansk Metalarbejderforbund: Lønoversigt for Provinsen, samt Statistiske Efterretninger.

styrkeforholdet mellem klasserne. Spejlbilledet af arbejdskraftens værdi er udbytningsgraden, som når alt er et spørgsmål om, hvor en del af det samlede værdiprodukt, der tilfalder arbejderklassen. Ændringer i arbejdskraftens værdi er altså et spørgsmål om ændringer af styrkeforholdet mellem klasserne. Vi behandler det prismæssige udtryk for disse ændringer ved at se på arbejdslфnnens generelle bevagelser.

9. Vi skal ikke her behandle årsagerne til, at der opsuges ekstraordinært meget arbejdskraft i værftsindustrien, men henviser til foranstående artikel "Skibsvarftskrise og massefyringer". 
steres over 65 mill. kr. på værftet i perioden 1974-77 (heraf knap halvdelen som EF- og statsstøtte). Den umiddelbare virkning er som nævnt en stigende beskæftigelse. Virkningerne heraf udebliver heller ikke, som det fremgår af figur 2.

Figurens lønkurve skal forstås således: hvis kurven ligger over 100 stiger arbejdslønnen på Frederikshavn Værft hurtigere end i industrien som helhed; det er tilfældet fra 1975 til midten af 1977. Ligger kurven under 100 stiger værftets lønninger langsommere end i industrien.

Man støder hyppigt på den forestilling, at investeringer sikre beskæftigelse og gode lønforhold. Umiddelbart kunne det også se sådan ud for Frederikshavn Værft. Men det er kun en midlertidig tendens, som straks slår om i sin modsætning: relativt faldende beskæftigelse og faldende arbejdsløn. Sammenhængene er følgende: den stigende akkumulation betyder, at der umiddelbart opsuges mere arbejdskraft. Den derved stigende efterspørgsel på arbejdskraft tvinger arbejdslønnen op. Tilstrømning af arbejdskraft, ${ }^{10}$ den fortsatte akkumulation og dens virkninger i form af teknologisk frisættelse af arbejdskraft og en mindre produktionsindskrænkning får værftets arbejdskraftefterspørgsel til at falde, og tvinger påny arbejdslønnen ned på værftet, således at den nu bevæger sig mere i overensstemmelse med den generelle bevægelse i arbejdslønnen, som iøvrigt (hvad reallønnen angår) er for nedadgående i periodens slutning.

Det lokale udbud og efterspørgsel på arbejdskraft er også afgørende for de svingninger i arbejdslønnen, som mystificeret kaldes for lønafsmitning. Hvis arbejdskraftudbudet er lille, vil én fabriks øget opsugning af arbejde gennem kapitalekspansion, fremtvinge lønstigninger, som fører til tilstrømning af arbejdere fra andre fabrikker, hvorved arbejdslønnen også dér kan tvinges op. Stigninger i arbejdslønnen på de andre fabrikker kan fremtvinges gennem en bevidst aktion: omgangsskruen (dvs. strejke eller trussel om strejke på omgang fra fabrik til fabrik); et eksempel herpå er automekanikernes lønaktion fra autoværksted til autoværksted, som endte med Scaniadam-sagen. Løfteparagraffen indenfor minimallønsområdet (vi behandler den senere) kan ses som en formalisering af omgangsskruen. Løfteparagraffen fastsætter i virkeligheden regler for varsling og anvendelse af omgangsskruen. Omgangsskruen fungerer på betingelser af arbejdsmarkedets mekanismer. Dens succes forudsætter, at det er arbejdskraftefterspørgslen, som er dominerende på det lokale arbejdsmarked, og ikke udbudet. Er arbejdskraftefterspørgslen vedvarende vil den industrielle reservearmé sætte sig i bevægelse (eller ka-

10. Fra april kvartal 1974 til april kvartal 1976 (hvor medlemstallet kuliminerer) stiger medlemstallet $\mathrm{i}$ Metalarbejderforbundets Frederikshavnsafdeling med 26,6\% jvf. Metalarbejderforbundets lønoversigt for Provinsen, diverse numre. 
pitalen vil bevæge sig hen til den), hvorved de lokale arbejderlønninger påny vil tilnærme sig arbejdslønnens generelle bevægelser.

I krisetid med voksende industriel reservearmé vil arbejdslønnen på f.eks. Frederikshavn Værft ikke kun falde på grund af det lokale arbejdsmarked, men også på grund af den generelt voksende industrielle reservearmé. Da de værftsfrisatte arbejdere ikke kan få anden beskæftigelse på grund af den voksende reservearmé, vil deres arbejdsløshed også stå som formidler af den industrielle reservearmé generelle tryk på arbejdslønnen, som på den måde forplanter sig gennem de lokale arbejdsmarkeder.

3. Forholdet mellem arbejdskvantum og variabel kapital. Den voksende industrielle reservearmé forstærker ikke kun konkurrencen mellem den beskæftigede og ubeskæftigede del af arbejderklassen; den virker også direkte ind på arbejdsvilkårerne for den beskæftigede del. Enhver kapitalist har interesse i, at der ydes mest mulig arbejde af færrest mulige arbejdere. Selvom det var muligt at købe samme mængde arbejde fordelt over flere arbejdere ligeså billigt eller endnu billigere, vil kapitalisten have objektiv interesse i beskæftigelse af færrest mulige arbejdere. Er den samme mængde arbejde fordelt over flere arbejdere, så vokser udlægget til den fixe del af den konstante kapital (altså udlægget til driftsmidlerne) med antallet af arbejdere. Fordeles arbejdet på færre arbejdere, formindskes udlægget til driftsmidlerne relativt. Eller sagt på en anden måde: med jo større arbejdsintensitet, der arbejdes, jo mere arbejde kan der opsuges af et givet maskineri, og jo mere økonomisk kan den fixe kapital anvendes.

Motivet til en sådan $\emptyset$ konomisering med fixkapitalen vokser med produktionens udvikling; den vokser med den akkumulation, som fører til den organiske sammensætnings stigning.

Akkumulationsudvikling i Danmark i 1960'erne og 1970'erne er usædvanlige derved, at årsudlægget til fixkapital for første gang i historien overstiger udlægget til den variable kapital. Det betyder, at $\varnothing$ konomisering med fixkapital gennem intensivering af arbejdet bliver et kraftigt voksende motiv i den kapitalistiske udvikling. Udviklingen fremgår tydeligt af tabel 1; tabellen skal forstås sådan: hvis tallene er under 100, så udgør den variable kapital det største $\emptyset$ konomiseringspotentiale; hvis tallene er over 100, er det fixkapitalen, som har det største $\varnothing$ konomiseringspotentiale. ${ }^{11}$

11. For at disse sammenhænge ikke skal opfattes for mekanisk må følgende præciseres: det, at det er fixkapitalen, som er det største økonomiseringspotentiale, betyder ikke nødvendigvis, at der faktisk $\emptyset$ konomiseres med fixkapitalen; det vil afhænge af den "lethed" (i værdimæssig forstand), hvormed $\emptyset$ konomiseringen kan gennemføres. Fixkapitalens relativ stigende betydning har en stoflig parallel, som må tages med i betragtning. Vokser fixkapitalen relativt er det samtidigt et udtryk for en ændring af produktionens tekniske basis og udvikling i arbejdets kooperation; svarende til denne ændring hører ændringer i økonomiseringens stoflige former. 
Tabel 1 Forholdet mellem kapitaludlæg til fixkapital og udlæg til variabel kapital. Fixkapital som procent af variabel kapital i årene 1960, 1968-1976.

\begin{tabular}{lcccccccccc}
\hline & 1960 & 1968 & 1969 & 1970 & 1971 & 1972 & 1973 & 1974 & 1975 & 1976 \\
\cline { 2 - 9 } Hele industrien & 73 & 138 & 140 & 140 & 155 & 161 & 172 & 194 & 212 & 204 \\
Værftsindustrien & 84 & 56 & 64 & 67 & 83 & 105 & 101 & 111 & 125 & 145 \\
\hline
\end{tabular}

Kilde: Industriel udvikling. Statistisk oversigt over kapitalrentabilitet m.v. TEK/SAMRUC, 1978, bd. I og II.

Økonomisering med fixkapital gennem arbejdsintensivering er ikke et specielt krisefænomen, men finder i ligeså stort udstrækning sted under den intensive kapitalakkumulation; hen mod krisen vokser motivet for denne $\varnothing$ konomisering; under selve krisen sker den imidlertid under andre former, som har betydning for arbejdslønnens bevægelser.

Virkningen af arbejdsintensiveringen er åbenlyst: det betyder, at tilførslen af arbejde vokser hurtigere end tilforslen af arbejdskraft, og videre: "Det merarbejde, der udføres af den beskæftigede del af arbejderklassen, får arbejderklassens reserver til at svulme, mens omvendt det forøgede tryk, reserverne udøver gennem deres konkurrence over for de beskæftigede, tvinger de beskæftigede til merarbejde og til at underkaste sig kapitalens diktat". ${ }^{12}$

Akkumulationen under den intensive periode fører på den ene side til teknologisk betinget relativ frisættelse af variabel kapital; herved forøges kapitalens organiske sammensætning; det fører på den anden side til et forøget motiv til $\emptyset$ konomisering med fixkapitalen gennem intensivering af arbejdet.

I den intensive akkumulationsperiode er den mest anvendte form for intensivering af arbejdet anvendelsen af intensitetsfremmende lønsystemer (altså de forskellige akkordlønsystemer). Størrelsen af akkordarbejdslønnen i forhold til timearbejdslønnen er et udtryk for den merpris på arbejdskraften, som kapitalisten er villig til at betale for at sikre sig, at der arbejdes med den større intensitet, som akkordlønsystemet normalt medfører.

Vokser reservearméen, så overtager dens skærpelse af konkurrencen mellem den beskæftigede og den ubeskæftigede del af arbejderklassen de intensitetsbetingede lønsystemers funktioner. Merprisen på det akkordlønnede arbejde forsvinder eller akkordlønsystemet forsvinder i dens hidtidige former. Disse tendenser fremgår af tabel 2. Arbejdsintensiteten kan fastholdes og tvinges yderligere op gennem reservearméens tryk.

12. Marx: Kapitalen, bd. 1:4, s. 896. 


\section{Table 2 Merpris på akkordarbejde. Akkordtimelønfortje- nesten i procent af timelønsfortjenesten indenfor Metalarbejderforbundet, hele landet, gennemsnit af kvartalsopgørelser.}

\begin{tabular}{llllllll}
\hline 1971 & 1972 & 1973 & 1974 & 1975 & 1976 & 1977 & 1978 \\
109,9 & 110,6 & 109,8 & 109,2 & 109.3 & 108,8 & 107,7 & 106,8 \\
\hline
\end{tabular}

Kilde: Diverse årgange af Metalarbejderforbundets lønoversigter. Der gøres opmærksom på, at akkordlønnede ikke nødvendigvis arbejder 100 procent på akkord; akkordtimeprocenterne varierer meget, hvorfor de reelle merpris kan udviskes noget; men udviklingstendensen er klar nok.

Tabellen skal forstås på den måde, at jo nærmere tallet er 100, jo mindre er forskellen mellem akkordtimefortjenesten og timelønsfortjenesten. Det må understreges, at her er kun antydet nogle sammenhænge; sidenhen behandler vi mere udførligt akkordlønsystemet og dets funktioner, ikke mindst over for udviklingen af lønforskelle.

4. Sammenfattende: Vi sagde i indledningen, at der ikke er en direkte sammenhæng mellem den samlede industrielle reservearmé og udviklingen af arbejdslønnen på en bestemt fabrik. Vi kan nu resumere, hvorfor det ikke er tilfældet, og hvordan sammenhængene må ses. Falder f.eks. arbejdslønnen på en bestemt fabrik, så kan det skyldes:

For det første arbejdslønnens generelle fald på grund af den voksende industrielle reservearmé, d.v.s. at den ubeskæftigede del af den samlede arbejderklasse vokser; i forhold til en enkelt fabrik formidles denne bevægelse over det lokale arbejdsmarked gennem tilstrømning af arbejdskraft fra andre regioner/brancher eller afvandring af produktivt fungerende kapital til andre regioner/brancher, altsammen som følge af den samlede industrielle reservearmés vækst.

For det andet kan det skyldes ændringer i det lokale arbejdsmarked, som betyder, at forholdet mellem udbud/efterspørgsel ændres i en sådan retning, at arbejdslønnen svinger nedad indenfor rammerne af arbejdslønnens generelle bevægelser. Disse svingninger kan bevæge sig i modsat retning af de generelle bevægelser af arbejdslønnen, men kun for en kortere tid, alt afhængig af det lokale arbejdsmarked.

For det tredie kan det skyldes, at svingningerne på det lokale arbejdsmarked og/eller den voksende industrielle reservearmé fjerner den merpris på arbejdskraft, som kapitalisten tidligere var blevet tvunget til at betale for en højere arbejdsintensitet. 
Under krisen vil disse tre forhold typisk virke samtidigt og $i$ samme retning med konsekvenser for arbejdslønnen i nedadgående retning. ${ }^{13}$

\section{Akkordlønsystemer og deres virkning på arbejdslønnen}

Det er ikke meningen her at gå i detaljer med de forskellige akkordlønsystemer, men nogle hovedprincipper skal dog anføres for at vi sidenhen kan behandle følgende problemstilling: sammenhængen mellem produktivitetsafhængige lønsystemer og reservearméens løntrykkende virkninger.

1. Forholdet timeløn og akkordløn. Med akkordlønsystemer mener vi alle de forskellige former for lønsystemer, hvor lønudbetalingen er gjort afhængig af den intensitet, som der arbejdes med. For at fjerne akkordlønsystemernes dårlige ry har man som bekendt omdøbt dem til produktivitetsfremmende lønsystemer, men akkord er det jo stadig; ${ }^{14}$ man kommer sagens kerne nærmere, hvis de kaldes for intensitetsfremmende lønsystemer.

Den internationale Arbejderorganisation (ILO) har foreslået følgende definition af produktivitetsfremmende lønsystemer: herved forstås en aflønningsform, som bygger på en nærmere fastsat afhængighed mellem den udbetalte løn og den hertil svarende indsats. ${ }^{15}$

Ved de produktivitetsfremmende lønsystemer/akkordlønsystemer kunne det derfor se ud som om arbejderen aflønnes efter værdien af hans indsats.

13. På dette punkt kan det være vigtigt endnu engang at præcisere, at vi behandler de mere almene bestemmelser uden direkte at inddrage fagforeningernes muligheder og rolle. Vi behandler emnet udfra den forudsætning, at vi vil vise de objektive betingelser for fagforeningspolitikken.

14. I Rapport vedrørende Produktivitetsfremmende lфnsystemer, udarbejdet af det mellem Landsorganisationen i Danmark og Dansk Arbejdsgiverforening i januar 1962 nedsatte underudvalg; København 1962, er der en tendens til - som så mange andre steder - at sætte akkordarbejde lig med stykbetalt arbejde i snæver forstand. Det afgørende ved akkordarbejde er ikke, at der er tale om stykbetaling af arbejdet; derimod - som det fremgår nedenfor - at arbejdet betales efter den intensitet, der arbejdes med. Stykbetaling er blot en af de mange måder at gøre arbejdsmængden op på. Hvis produktionsresultatet ikke er stykdelt (som f.eks. ved svejsning), må arbejdsintensiteten måles på en anden måde (f.eks. ved arbejdsstudier). Men uanset måle- eller opgørelsesmetode er der tale om akkord; der er ingen kvalitativ forskel.

15. Her efter Rapport vedrørende Produktivitetsfremmende lфnsystemer, op.cit., s. 1. Den pågældende ILO-publikation hedder Introduktion til Arbejdsstudier, København 1961. 
Men akkordlønnen er blot en forvandlet form for timeløn; forskellen mellem dem er formen for udbetaling af arbejdslønnen. Ved stykbetaling eller anden akkordbetaling bliver arbejderen ikke lønnet for værdien af det produkt, han har ydet, eller værdien af den produktmængde, han i tillæg har ydet. Derimod aflønnes han efter den produktmangde, hans arbejde genstandgør sig i over en given tid. Produktmængden bliver altså et mål for det ydede arbejde. Ved timelønnen måles arbejdet ved dets varighed i tid. ${ }^{16}$

Akkordløn og timeløn kan betragtes som to forskellige måder at måle arbejdsydelsen på, og har intet at gøre med produktets eller arbejdets værdi. Køber kapitalisten akkordlønnet arbejdskraft og betaler han den med en merpris i form af højere timefortjeneste, så er størrelsen af merprisen altså ikke bestemt af, hvor værdifuldt akkordarbejdet er for kapitalisten, men derimod af, hvor meget større arbejdsmængde han sikrer sig pr. arbejdstime sammenlignet med en timelønnet arbejdskraft.

Akkordløn har altså den egenskab, at den på den ene side "... giver kapitalisten et nøjagtigt mål for arbejdets intensitet", ${ }^{17}$ og på den anden side, at der kun betales efter denne intensitet.

Der findes en række forskellige akkordlønsystemer, såsom: bevægelsesorienterede systemer (MTM, m.v.); arbejdstaktorienterede systemer (f.eks. priskurant på meter svejsesøm); aftale akkord (f.eks. aftalt dagløn på basis af en beskrivelse af dagens arbejdsmængde); bonus (f.eks. løntillæg, hvis bestemt arbejdsmænde nås pr. dag). Trods forskelligheden har alle akkordlønsystemer det fælles, at hele eller dele af abejdslønnen udmåles på basis af arbejdsmængden, altså arbejdsintensiteten.

Kapitalistens interesse i indførelsen af akkordlønsystemer hænger som allerede sagt udelukkende sammen med arbejdsintensiveringen. Akkordlønsystemer har imidlertid nogle følgevirkninger, som kort skal nævnes: ved akkordlønsystemer skal kapitalisten anvende mindre arbejdskraft på opsyn med produktionens forløb, fordi kontrollen med arbejdets intensitet og kvalitet sker gennem selve lønformen; akkordlønsystemet vil automatisk udpege og gøre det lettere for kapitalisten at skille sig af med den arbejder, som arbejder under den normale intensitetsgrad, f.eks. på grund af svigtende udholdenhed m.v.

2. Akkordlønsystemernes kapitalistiske virkninger. Akkordlønsystemernes forskellighed afspejler i stor udstrækning udviklingsniveau i mekaniseringsgrad og arbejdsorganisation, samt i hvor stor udstrækning fagforeningerne 
har været i stand til at hindre de mest bestialske former for akkordløn. ${ }^{18}$ Sammenhængen mellem akkordlønsystemer og mekaniseringsgrad/arbejdsorganisation må ikke forstås sådan, at f.eks. en bestemt mekaniseringsgrad fører til et bestemt akkordlønsystem, men derimod sådan: en række akkordlønsystemers anvendelse forudsætter en bestemt udviklingsgrad af maskineriet. Afgørende er imidlertid, at akkordlønsystemer ikke indføres på grund af deres funktionalitet over for en given teknologi eller arbejdsorganisation, men derimod på grund af deres kapitalistiske virkninger i form af stigende profitproduktion.

Den kapitalistiske virkning af akkordlønsystemerne angår i forskellig omfang økonomisering med alle de forskellige dele af kapitalen: variabel kapital (arbejdslønnen), den fixe del af den konstante kapital (maskiner og andre driftsmidler) og den flydende del af den konstante kapital (råvarer, hjælpestoffer, m.v.). Akkordlønsystemernes virkninger afhænger af arbejdsintensiveringens virkninger på udlægsstørrelsen på de forskellige kapitaldele.

Akkordlønsystemer har direkte virkninger på den variable kapitals størrelse. Fordobles arbejdstempoet, halveres den variable kapitals størrelse. Arbejdsintensiveringen kan antage to grundformer, som dog i praksis ofte er sammenblandet. For det første kan den bestå i at fjerne arbejdsdagens naturlige pauser i produktionen gennem arbejdstidsbesparende sammenstykning af arbejdsprocessens enkelte delprocesser (f.eks. gennem indførelse af transportbånd). Som eksempel kan nævnes udviklingen i slagteribranchen i 1950'erne og 1960 'erne. ${ }^{19}$ For det andet kan arbejdsintensiveringen bestå i en forøgelse af bevægelsesintensiteten i de enkelte arbejdsoperationer. Det har en direkte virkning på økonomiseringen med den fixe kapital, idet den stigende arbejdsintensitet betyder, at der opsuges mere arbejde af et givet maskineri, som igen betyder (relative) besparelser på fixkapitalen (problemstillingen er tidligere behandlet under lønbevægelsesafsnittet, jvf. især her tabel 1).

Hvis den organiske sammensætning af kapitalen vokser over et bestemt niveau, så vil arbejdsintensiveringens profitmæssige virkninger være større gennem $\varnothing$ konomisering med fixkapitalen end gennem den variable kapital. Under disse omstændigheder kan det betyde, at de relative lønbesparelser ved akkordarbejdet er af sekundær betydning; det vigtigste er økonomiseringen med maskineriet. Den stigende organiske sammensætning vil betyde en forskydning fra bevægelsesorienterede akkordlønsystemer til bonusorienterede akkordlønsystemer, fordi arbejdsintensiveringens formål i mindre grad er arbejderens

18. Ikke mindst på grund af arbejdermodstand blev elementtidsstudierne (f.eks. MTM-systemet) aldrig særlig udbredt i industrien herhjemme i 1960'erne. I dag er MTM-systemet kun anvendt på et fåtallig fabrikker.

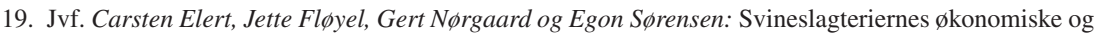
teknologiske udvikling; RUC-TEK/SAM, 1978, kap. 3 \& 4. 
energiudfoldelse, og i stigende grad er den anvendte maskintid i forhold til en given produktmængde. 1970'ernes udprægede afskaffelse af de bevægelsesorienterede lønsystemer ${ }^{20}$ til fordel for bonusorienterede lønsystemer er dels et resultat af fagforeningernes voksende modvilje mod akkordlønsystemet, men er dels også udtryk for akkordlønsystemernes ændrede kapitalistiske virkninger for henholdsvis den variable og den fixe kapital.

Der findes eksempler på, at fixkapitalens størrelse direkte er indregnet i akkordlønsystemet. Støberibranchen er én af de brancher, hvor udlægget til fixkapitalen i forhold til den variable kapital er størst. I begyndelsen af 1960'erne var fixkapitalen udregnet som procent af variabel kapital på omkring 175\% (hele industriens var 73\%); i 1975 var procenten steget til 416, kun overgået af mineralolieindustrien (hele industrien var på 212\%). Dette forhold har præget de lønsystemer, som har været anvendt i branchen. Et eksempel på støberibranchens lønsystemer skal nævnes. I 1958 indførte et støberi efter omfattende investeringer et akkordlønsystem, hvor der blev udbetalt bonus, som var fastsat på grundlag af et normtal. Normtallet ændres med øget mekaniseringsgrad, idet den indgår i aftalen som en maskinprocent, der er den procent af den samlede produktionstid, som udføres på maskine. Indføres der mere maskineri, vokser maskinprocenten, og der skal ydes en i forvejen fastsat ekstra produktionsmængde for at opnå samme bonustillæg som tidligere. ${ }^{21}$

Umiddelbart kunne det se ud som om, at der også findes akkordlønsystemer, som ikke angår arbejdets intensitet, men derimod påpasselighed med råvarer og produktets kvalitet, f.eks. i form af råvarebonus og kvalitetsbonus. Det er imidlertid ikke tilfældet, som nogle eksempler vil vise. Det drejer sig stadig om arbejdsintensiteten, men om abejdsintensitetens virkninger på størrelsen af udlægget til den flydende del af de konstante kapital.

Akkordlønsystemernes virkninger på økonomisering med den flydende del af den konstante kapital (råvarer, m.v.) er som regel indirekte. Ved en række produktioner er forudsætningen for at holde akkorden afhængig af råvarernes kvalitet. Råvarer af ringere kvalitet eller råvarer, som er vanskeligere at anvende, forøger derfor mængden af det arbejde, som opsuges pr. produkt. Skal arbejderen kunne holde akkorden, fører det til et større råvarespild. For at modvirke det har man eksempelvis i tobaks- og tekstilindustrien $^{22}$ indført bonusordninger på besparelser på råvarer. Bonusordningerne virker som præmie, som udbetales oveni det eksisterende bevægelsesorien-

20. Jvf. f.eks. Poul Larsen: Lønsystemer, Teknologisk Institut, 1976, s. 23-24.

21. Jvf. Rapport vedrørende Produktivitetsfremmende lønsystemer, op.cit,, bilag 7: Produktionstillægsordninger i støberier.

22. Jvf. Rapport vedrørende Produktivitetsfremmende lønsystemer, op.cit., bilag 15: Råvarebonus indenfor cigarindustrien; og bilag 16: Råvarebonus på tekstilfabrik. 
terede akkordlønsystem. Umiddelbart kan det se ud som om, der blot gives præmie for påpasselighed med kapitalistens ejendom; men det er mindre end den halve sandhed. I virkelighden gives der præmie for at arbejde med en given intensitetsgrad, også med den del af råvarerne, som kræver ekstra kvantum arbejde. Eller: årsagen til indførelse af råvarebonus kan ses som et resultat af, at den hidtil anvendte lønform ikke giver den fulde kontrol med arbejdsintensiteten i forhold til hele mængden af råvarer. Hullerne dækkes med den nævnte råvarebonus.

Det samme forhold gør sig gældende for kvalitetsbonusordninger. Ved de fleste akkordlønsystemer forudsættes det, at akkordbetaling kun ydes på det arbejde, som er udført til én af kapitalisten fastsat kvalitet. Hvis produktkvaliteten ikke er afhængig af én enkelt arbejder, men af en række forhold af både teknisk og arbejdsfunktionsmæssig art langs hele produktionskæden, ses det hyppigt, at der indføres en samlet bonusordning på produktkvaliteten sideløbende med de individuelle akkorder. ${ }^{23}$

Hvis en stigende arbejdsintensitet fører til en stigende kassationsprocent, medfører det, at der ganske vist tilsættes mindre arbejde pr. produkt på grund af intensiveringerne, men det modgås af, at der tilsættes mere arbejde pr. anvendeligt produkt på grund af den stigende kassationsprocent. Men ikke nok med det: stigende kassationsprocent har også konsekvenser for den økonomiske anvendelse af såvel råvarer som maskineri. Hvis råvarerne og/eller det anvendte maskineri er forholdsvis kostbart, vil kapitalisten se sin fordel i at indføre et lønsystem, som balancerer mellem intensitetsforøgelse og kassationsprocenter. Som eksempel kan nævnes en kemisk-teknisk virksomhed, ${ }^{24}$ hvor der betales bonus pr. styk, produceret udover en bestemt norm, og hvor der fradrages bonus pr. styk, som sorteringsafdelingen ikke kan godkende.

De kapitalistiske betingelser for indførelse og bibeholdelse af akkordlønsystemet hænger altså sammen med mulighederne for at forøge og/eller fastholde arbejdsintensiteten. Hvis produktionens subjektive moment er forsvindende, hvis arbejdet i produktionsprocessen er reduceret i et sådan omfang og på en sådan måde, at arbejdsintensiteten $\mathrm{i}$ alt væsentlig er bestemt af det anvendte maskinsystem, mister akkordlønsystemet sit objektive grundlag. ${ }^{25}$ Og videre: hvis akkordlønsystemet har fremtvunget en arbejdsintensitetsforøgelse, således at de - omend individuelt forskellige - fysiologiske grænser er nået, mister ak-

23. Således eksempelvis på Kastrup Glasværk; jvf. AMØ-gruppen: Kastrup Glasværk. En analyse af teknologi, løn og kvalifikationsudvikling; RUC-TEK/SAM, 1977, kap. 2, s. 34-69.

24. Jvf. Rapport vedrorende Produktivitetsfremmende lønsystemer, op.cit., bilag 19: Produktionstillægsordning med kvalitetsklausul i kemisk-teknisk virksomhed.

25. Det gælder både for kapitalisten og arbejderen, men af forskellige grunde. For kapitalisten, fordi akkordlønsystemet ikke længere kan sikre en $\emptyset$ get intensitet; for arbejderen, fordi akkordlønsystemet ikke længere kan sikre en overgennemsnitlig løn. (Jvf. senere om udviklingen på Frederikshavn Værft). 
kordlønsystemet ligeledes sit objektive grundlag som intensiveringsinstrument, og måske også grundlaget som instrument til opretholdelse af en given intensitetsgrad, specielt hvis arbejdsintensiteten kan opretholdes på andre og for kapitalisten billigere måder, f.eks. gennem det tryk, som en voksende reservearmé medfører.

Specielt i to sammenhænge kan det subjektive spillerum forøges, og dermed løbende forny akkordlønsystemets objektive grundlag. Ved afkortningen af arbejdsdagens længde forekommer der muligheder for at intensivere arbejdsdagen yderligere, fordi den fysiologiske grænse flyttes; og ved en ny indretning af produktionsprocessen dels ved ændringer i teknologien og dels ved ændringer i arbejdsorganisationen. Vi skal imidlertid ikke gå nærmere ind på disse forhold her. ${ }^{26}$

3. Akkordlфnsystemets virkninger på arbejdslфnnen. I lønbevægelsesafsnittet behandlede vi almene bestemmelser vedrørende akkordlønnen. Merprisen ved indførelse af akkordlønsystemer måtte især under den intensive kapitalakkumulation ses som et udtryk for den merpris på arbejdskraften, som kapitalisten var villig til at betale for at sikre sig den højere arbejdsintensitet, ikke mindst på grund af arbejdsintensiveringens voksende virkninger på $\varnothing$ konomiseringen med den fixe kapital.

Som afslutning på dette afsnit skal vi kort se på det etablerede akkordlønsystems virkninger på arbejdslønnen.

På en fabrik vil et akkordlønsystem bevirke, at der udvikles individuelle lønforskelle, svarende til individuelle forskelle i den intensitetsgrad, som de enkelte arbejdere arbejder med. Et indtryk af lønforskelle på en enkelt fabrik (Lindøværftet) kan fås af tabel 3.

På Lindøværftet er lønforskellene på den ene side resultat af forskellige akkordlønsystemer i de forskellig afdelinger, af forskellige grader af arbejdsintensitet, og af forskellig omfang af teknologisk udvikling i de enkelte afdelinger, m.v., og på den anden side modificeret af klubbernes indbyrdes aftalte akkordlofter, som skal hindre udhuling af akkordlønsystemerne gennem en sænkning af priskuranter pr. mængde ydet arbejde. Ikke desto mindre er der tale om en udpræget løndifferentiering, ikke mindst når man tager i betragtning, at alle er medlem af det samme forbund, og derfor underkastet resultaterne af den samme lønpolitik.

Udviklingen af individuelle arbejderlønninger ændrer imidlertid intet ved de bestemmelser, som gælder for arbejdslønnens generelle bevægelser, bestemt

26. Et eksempel skal imidlertid nævnes: ved forkortelse af arbejdsugen fra 48 til 45 timer i 1960 steg produktiviteten pr. time med 3,8\% på Kastrup Glasværk. Det er en relativ stor stigning i kraft af, at der er tale om en maskinel produktion, hvor arbejdsoperationerne er vedligeholdelsesoperationer; jvf. Nordisk Glasindustris samarbejdskomitté; 11. ordinarie mötet, i Helsingfors, 29-30. augusti, 1961. 
Tabel 3 Individuelle lønforskelle på Lindøværftet; gennemsnitlig timefortjeneste eksklusiv dyrtidstidstillæg; sammenlignet med lønniveauet i Metalarbejderforbundets Odenseafdeling og med hele Metalforbundets lønniveau. Januar kvartal, 1978.

\begin{tabular}{lccc}
\hline & $\begin{array}{c}\text { Arbejdsløn } \\
\text { på Lind } \varnothing\end{array}$ & $\begin{array}{c}\text { I pct. af } \\
\text { Odenseafd: }\end{array}$ & $\begin{array}{c}\text { I pct. af } \\
\text { landsgennemsnit: }\end{array}$ \\
\cline { 2 - 4 } AKKORDLøN: & & & \\
Højeste: & 30,77 & 120 & 119 \\
Midten: & 26,99 & 105 & 104 \\
Laveste: & 20,84 & 81 & 81 \\
TIMELØN: & & & \\
Højeste: & 27,73 & 108 & 107 \\
Midten: & 22,54 & 88 & 87 \\
Laveste: & 16,94 & 66 & 66 \\
\hline
\end{tabular}

Kilde: Metalarbejderforbundets lønoversigt samt oplysninger fra værftet. Lindølønningerne er eksklusiv værftets dyrtidstillæg på 17,00 kr. For at gøre tallene sammenlignelige er Odenseafdelingens og hele Forbundets gennemsnitlige timefortjeneste (samlet for både akkordog timelфn) på henholdsvis 42,60 kr. og 42,86 kr. fratrukket dyrtidstillægget.

gennem reservearméens størrelse, og modificerer kun i begrænset omfang de bestemmelser, som gælder for arbejdslønnens svingninger på grund af det lokale arbejdsmarked.

På den ene side vil akkordlønsystemerne hyppigt skærpe konkurrencen mellem arbejderne indbyrdes på fabrikken; virkningerne heraf vil for det første blive en tendens til at hæve de individuelle arbejderlønninger op over arbejdslønnens gennemsnitsniveau; for det andet vil det medføre en tendens til at sænke fabrikkens gennemsnitsniveau. Af tabel 3 ses det, at akkordlønnen på Lindøværftet ligger ligeså meget under som over landsgennemsnittet og Odensegennemsnittet for time- og akkordløn. De individuelle lønforskelle på én enkelt fabrik må derfor betragtes som helhed; fabrikkens gennemsnitsløn vil stadig være underkastet de tidligere nævnte bestemmelser vedrørende arbejdslønnens størrelse og svingninger.

På den anden side vil et allerede etableret akkordlønsystem kunne virke som en barriere mod en umiddelbart voksende arbejdsløsheds virkninger i området, fordi kapitalisten med akkordlønsystemet har købt og betaler arbejdskraften efter mængden af ydet arbejde, og altså ikke umiddelbart betaler efter arbejdsmarkedets svingninger. I mange tilfælde er det imidlertid en yderst skrøbelig 
barriere, fordi de fleste akkordlønsystemer har indbygget direkte eller indirekte forringelser af stykbetalingen. ${ }^{27}$

Efter nu at have behandlet årsagerne til arbejdslønnens størrelse og dens svingninger, og akkordlønsystemets virkninger på arbejdslønnen mere alment, skal vi behandle disse problemstillinger konkret og eksemplarisk med udgangspunkt i værftsindustriens akkordlønsystemer og systemernes ændringer, samt lønudviklingen indenfor værftsindustrien.

\section{Værftsindustriens lønsystemer i krisen}

Hovedparten af alle arbejdere indenfor værftsindustrien er medlemmer af Metalarbejderforbundet, uanset om de er faglærte eller tillærte (specialarbejdere). Det betyder, at værftsarbejdernes lønforhandlinger sker indenfor rammerne af det bevægelige lønsystem (minimallønsområdet). Minimallønnen fastsættes centralt ved de generelle overenskomster, men den såkaldte løfteparagraf åbner mulighed for lokale lønforhandlinger i løbet af den fastsatte overenskomstperiode.

Det bevægelige lønsystem giver afgørende muligheder for at gennemtvinge lønstigninger, når det lokale arbejdsmarked skrumper ind, fordi lønnen i praksis stort set udelukkende forhandles lokalt, og ikke vil være afhængig af de betingelser, som afgører den generelle overenskomsts lønfastsættelser. Lidt firkantet kunne man sige, at det bevægelige lønsystem giver første prioritet til det lokale arbejdsmarkeds svingninger, mens normallønsystemet (hvor lønnen og de løbende lønstigninger fastsættes fra generel overenskomst til generel overenskomst) giver første prioritet til arbejdslønnens generelle bevægelser, betinget af reservearméens størrelse. Det skal ikke forstås sådan, at det bevægelige lønsystem sætter sig udover arbejdslønnens generelle bevægelser, men kun på den måde, at det bevægelige lønsystem har en større inerti, især i situationer med nedadgående tendenser i arbejdslønnens generelle bevægelse; samtidigt med at det bevægelige lønsystem er mere sårbar overfor lokalt voksende reserver.

Værftsindustrien har været krisepræget fra i det mindste midten af 1960'erne; det har over hele perioden ført til en generelt stagnerede beskæftigelse i værfts-

27. Betalingsforringelsen er direkte indbygget i de lønsystemer, som bygger på normalpræstation, og på et løntillæg for præstationer udover normen, idet normen hele tiden vil ændre sig, hvis den er baseret på direkte studier. Hvis en priskurant (betaling for nærmere angivet mængde arbejde) ikke er dyrtidsreguleret, vil inflationen på samme måde forringe stykbetalingen. Indførelsen af ny produktionsteknologi bruges også hyppigt som argument for ringere betaling af given mængde arbejde. Vi vender tilbage til problemstillingen i det efterfølgende. 
industrien, men i perioder, især fra 1971 til 1975, har der været tale om stigende beskæftigelse frem til de store fyringer, som begyndte i 1976; samtidigt er beskæftigelsen vokset specielt i 1970'erne indenfor Metalarbejderforbundets anden store branche: jern- og metalindustrien. Beskæftigelsessvingningerne fremgår af figur 3.

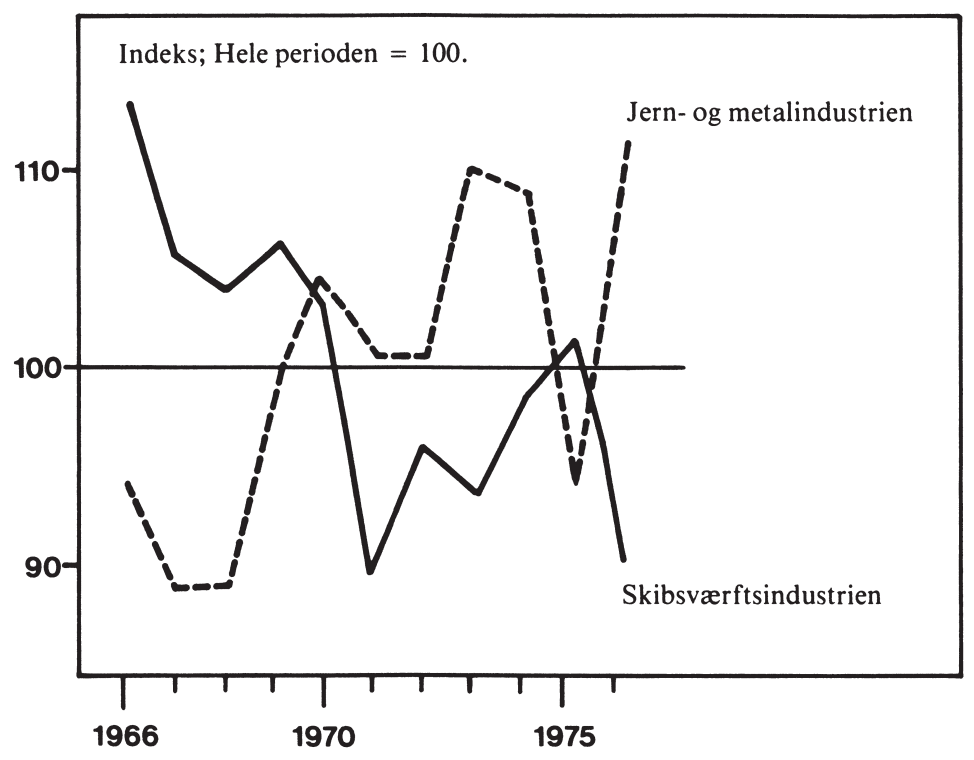

Figur 3. Svingninger i beskæftigelsen for Jern- og metalindustrien og værftsindustrien. Beskæftigelse som procent af hele periodens gennemsnitsbeskæftigelse for de to brancher. Kun arbejdere.

Et tredie forhold som er karakteristisk for værftsindustrien er, at der arbejdes i meget udpræget grad på akkord. For det første arbejder de, som er på akkord, stort set 100 procent på akkord, og for det andet er hovedparten af arbejderne på akkord. Over tid og fra værft til værft svinger antallet af arbejdere på akkord mellem ca. 65-95 procent, bortset fra enkelte un dtagelser, som vi senere vender tilbage til (f.eks. har Frederikshavn Værft nu kun 20 procent på akkord). Som sagt arbejder akkordarbejderne stort set 100 procent på akkord; men det er noget forholdsvist nyt, især på provinsværfterne; før 1975 var akkordprocenten 95 for provinsværfterne; før 1970 var den endnu lavere.

De tre nævnte forhold: det bevægelige lønsystem, en i gennemsnit stabiliseret beskæftigelsessituation og en udpræget anvendelse af akkordarbejde har haft afgørende betydning for værftsarbejdernes muligheder for at sikre sig en rimelig lønudvikling frem til krisegennemslaget i branchen. 
Med det store omfang af akkordarbejde og akkordtimeforbrug spiller den almindelige timelønsbetaling en meget lille rolle. På baggrund af løfteparagraffen er mulighederne til stede for at hæve akkordsatserne i forhold til prisstigningerne, hvorved en sikring af reallønnen umiddelbart er til stede, men afgørende for at reallønnen kan sikres er den styrkesvaghed, som svingningerne på det lokale arbejdsmarked stiller skibsværftsarbejderne overfor.

På grund af akkordlønsystemets sammenhæng mellem arbejdsintensitet og betalingssatser på arbejdsmængde kan reallønnen sikres på to måder: forøgelse af arbejdsintensiteten og forbedring af akkordsatser. En samlet oversigt for hele værftsindustrien viser, at skibsværftarbejderne har sikret sig en forbedret realløn gennem forbedrede akkordsatser i perioden 1972-75 (incl), mens reallønsforbedringer i den nærmest foregående og efterfølgende periode er sikret gennem arbejdsintensiveringen. Det fremgår af tabel 4.

Tabel 4 Den procentvise årlige stigning i teknisk arbejdsproduktivitet (udtryk for arbejdsintensiveringen) og samlet udbetalt gennemsnitlig realtimefortjeneste for skibsværfsbranchen i perioden 1965-1976.

\begin{tabular}{lcc}
\hline & Arbejdsproduktivitet: & Realtimefortjenste: \\
1965 & 17,0 & 5,3 \\
1966 & $-1,5$ & 9,8 \\
1967 & $-3,3$ & 8,2 \\
1968 & 7,9 & 7,2 \\
1969 & 17,7 & 5,2 \\
1970 & 4,8 & 7,2 \\
1971 & 16,0 & 4,7 \\
1972 & 6,4 & 11,9 \\
1973 & 4,5 & 9,2 \\
1974 & 1,2 & 14,1 \\
1975 & 0,5 & 9,9 \\
1976 & 8,4 & 9,4 \\
\hline
\end{tabular}

Kilde: Beregninger på basis af: Industriel udvikling. Statistisk oversigt over kapitalrentabilitet m.v. TEKSAMRUC, 1978, bd. II.

Tabellen skal forstås sådan: at stigningsprocenterne for realtimefortjenesten højere end procenten for stigningen i den tekniske arbejdsproduktivitet skyldes det forbedringer i akkordsatserne; er det omvendte tilfældet skyldes det forringelser af akkordsatserne (eventuelt også akkordlønsystemforringelser). 
De store stigninger i arbejdsintensiveringen i perioden 1969-72 skyldes ændringer i akkordlønsystemerne. Den ringe stigning i arbejdsintensiveringerne i årene 1972-75 skyldes ikke ændringer i akkordlønsystemer, men derimod investeringer og produktionsomlægninger. ${ }^{28}$

\subsection{Kort rids af den hidtidige udvikling i skibsværfternes akkordlønsystemer}

Indenfor skibsværftsindustrien har der såvidt vides ikke været anvendt ren akkord i de seneste årtier, men derimod blandet akkord. ${ }^{29}$ Ved ren akkord er der en direkte sammenhæng mellem arbejdsintensitet og arbejdsløn (jvf. fig. 4); ren akkord forudsætter, at akkordsatserne dyrtidsreguleres. Ved blandet akkord betales der dels en arbejdsløn, der er afhængig af arbejdsintensitet, og dels en fast lønandel; for skibsværfterne har denne faste lønandel udpræget været et dyrtidsreguleret grundbeløb, medens akkordsatserne ikke har været dyrtidsreguleret (jvf. fig. 5). Ved blandet akkord er sammenhængen mellem arbejdsintensitet og arbejdslønnens samlede størrelse således ikke proportionalt.

I 1967 foreslog Handelsministeriets kontaktudvalg vedrørende skibsvarfter, ${ }^{30}$ at man indenfor branchen nedsatte et udvalg, som kunne komme med forslag til forbedringer af lønsystemerne indenfor værfterne. Specielt var man fra ud-

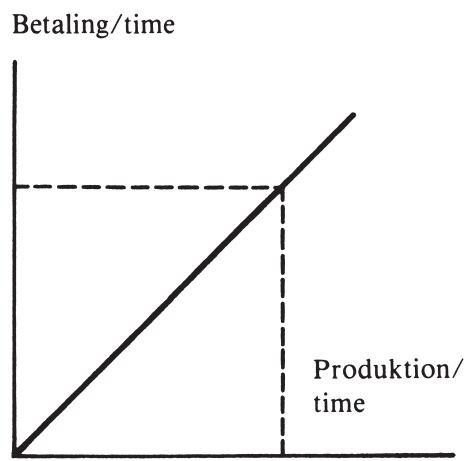

Fig. 4: Ren akkord.

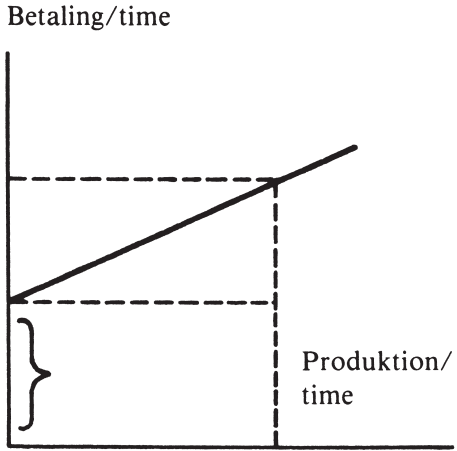

Fig. 5: Blandet akkord.

28. Jvf. den foranstående artikel "Skibsværftskrise og massefyringer".

29. Jvf. Rapport vedrorende Skibsvarfternes Lonsystemer, afgivet af det af Jern- og Metalindustriens Sammenslutning og Centralorganisationen af Metalarbejdere i Danmark nedsatte fællesudvalg; 1968, s. 5, hvor det hedder: "Da man ikke på skibsværfterne har indregnet dyrtidstillægget i akkorderne, er værfternes såkaldte rene akkorder i realiteten blandet akkord med dyrtidstillægget som fast lønandel".

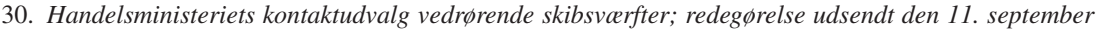
1967, s. 7. 
valgets side interesseret $i$, at man drøfter" ... mulighederne for hensigtsmæssigheden af, at der i forbindelse med kontaktafslutning kan træffes aftale med et værfts arbejdere eller med grupper af arbejdere om de granser for timetal og samlet lфnsum, indenfor hvilken det pågældende arbejde må holdes". Det er interessant, at kontaktudvalget allerede i 1967 foreslog et lønsystem, som senere er blevet kendt som Nakskov-lфsningen.

Jern- og metalindustriens Sammenslutning (arbejdsgiverne) og Centralorganisationen af Metalarbejdere nedsatte da også i slutningen af 1967 et udvalg, som imidlertid arbejdede på andre forslag end kontaktudvalget havde foreslået.

Udvalget udarbejdede en unders $\varnothing$ gelse af de eksisterende lønformer indenfor værftsindustrien, jvf. tabel 5.

Tabel 5 Anvendelsesomfang af forskellige lønsystemer indenfor værftsindustrien i 1967 (januar og april kvartal). Angivet i procenter.

$$
\text { REN TIDLØN }
$$

Timeløn:

TIDLØNSPRÆGEDE LØNFORMER

Procentakkorder:

Bonus:

\section{AKKORDL $\varnothing \mathrm{N}$}

Slumpakkorder:

Prislister:

Forhandlingsakkorder:

Arbejdsstuderede akkorder:

Beregnede akkorder:
$14,5 \%$

$33,0 \%$

$15,0 \%$

$8,0 \%$

$14,5 \%$

$9,5 \%$

$3,0 \%$

$2,5 \%$

Kilde: Rapport vedrørende Skibsværfternes lønsystemer, Kbh. 1968, s. 14.

Udvalget kom ikke med konkrete forslag til lønsystemer, men derimod med en "arbejdsplan", som primært skal sikre, at der på de enkelte værfter skete ændringer i lønsystemerne. Udvalget var dog - slet skjult - varm fortaler for arbejdstidsstudier og elementtidsstudier. Her var udvalget på linie med branchens arbejdsgivere, og delvis på linie med branchens tillidsmænd. Arbejdsgiverne henstillede til udvalget "... at anbefale indførelsen af arbejdsstudier og at opstille retningslinier for lokalaftalerne og betalingsfaktorernes antal samt 
at drøfte spørgsmålet om fordeling af akkordoverskud i fællesakkorder”. Det sidste, fordi arbejdsgiverne var tilhænger af, at akkordoverskuddet i fællesakkorder skulle fordeles ligeligt mellem alle arbejdere, mens arbejdersiden ved lokale forhandlinger havde krævet, at fordelingen skulle ske ud fra den enkeltes præstation og den fastsatte timefaktor. Til udvalget foreslog tillidsmændene: "... at man søger akkordområderne udvidet mest muligt, bl.a. også ved hjælp af arbejdsstudier - flere klubber har allerede indgået aftaler herom". ${ }^{31}$ Tillidsmændene er udover arbejdsstudierne tilhænger af, at arbejdsvurdering og personbedømmelse anvendes i større udstrækning som grundlag for akkord og bonus.

Selvom arbejdsgiverne og tillidsmændene er enige om indførelse af arbejdsstudier i større omfang, så kan der dog i udvalgets rapport spores en lang række konkrete uenigheder, som ikke hænger sammen med arbejdsstudiespørgsmålet, men derimod med det lønmæssige grundlag for anvendelsen af arbejdsstudier.

Hvorom alting er, så kommer arbejdsstudierne (som består af tre dele: metodestudier, tillægsstudier og operationstidsstudier ${ }^{32}$ ) til at dominere udviklingen af lønsystemerne i værftsindustrien de efterfølgende år. For kapitalisten er arbejdsstudierne på daværende tidspunkt et spørgsmål om at forøge arbejdsintensiteten (jvf. arbejdsintensitetstallene for henholdsvis 1966-68 og 1969-71 i tabel 4) for gennem denne forøgelse både at økonomisere med den variable og den fixe kapital. For tillidsmændene er arbejdsstudier et spørgsmål om at sikre forsvaret for realtimefortjenesten, som ikke mindst blev aktuel gennem den faldende beskæftigelse i 1968-71. At beskæftigelsesfaldet delvis skyldes de stigende arbejdsintensiveringer formindskede ikke problemet for værftsarbejderne i perioden (arbejdsintensiveringen steg med 43\%; beskæftigelsen faldt med 15\%).

\subsection{Lønsystemerne og krisen}

Medens akkordlønsystemernes udvikling på værfterne fra 1968 og frem til krisen ret entydigt er gået på indførelse af arbejdstidsstuderede akkordlønsystemer, forekommer der under krisen udvikling af akkordlønsystemer i forskellig retning, som kan sammenfattes i:

31. Rapport vedrørende Skibsvarfternes Lønsystemer, op.cit., s. 13.

32. Indhold og anvendelse er fastlagt i Sammenslutningens og Centralorganisationens rammeaftale om arbejdsstudier (§6), og omfatter: Metodestudier, som har til formål at fastlægge den mest hensigtsmæssige måde at udføre arbejdet på. Tillagstidsstudier, som foretages for at finde den tid, som udover den direkte operationstid medgår til arbejdets udførelse. Operationstidsstudier, som udføres for at finde frem til den tid, som en arbejder med normalydelse vil anvende på den givne arbejdsoperation. Jvf. Rapport vedrørende Skibsvarfternes Lфnsystemer, op.cit., s. 20-21. I afsnit "3.4. Lindøaftalen" er gennemgået et eksempel på en konkret udformning af et lønsystem efter disse retningslinier. 
1. Akkordlønsystemer med bonus, fast timeforbrug og fast timeløn pr. skib (Nakskov-løsningen; svarende til Kontaktudvalgets forslag fra 1967).

2. Bevarelse af akkordlønsystemer baseret på arbejdstidsstudier, i nogle tilfælde med modifikationer.

3. Akkordlønsystemernes afskaffelse til fordel for timeløn.

Denne udvikling i akkordlønsystemerne er udtryk for en række forhold, hvor det mest iøjnefaldende er svingningerne i de lokale arbejdsmarkeder, som har været afgørende for klubbernes og tillidsmændenes styrke; men også akkumulationsforløbet på de enkelte værfter, som i nogle tilfælde har mindsket de eksisterende akkordlønsystemers tekniske og arbejdsintensiveringsmæssige relevans for kapitalen - endog i nogle tilfælde udgjort en direkte hindring for en profitabel akkumulation.

Der er ingen tvivl om, at de eksisterende akkordlønsystemer i en række tilfælde har fungeret som en barriere mod det tryk, som de lokalt voksende reservearméer har udøvet mod de beskæftigede værftsarbejdere. Derfor har forsvaret for reallønnen ikke indskrænket sig til en kamp for akkordsatsernes realstørrelse, men også til en kamp for bevarelse eller forbedring af akkordlønsystemerne.

Metalarbejderforbundet og arbejdsgivernes politik har fra 1975 - såvel som i den foregående periode - været enslydende, omend med forskellig baggrund. Arbejdsgiverne ville sikre deres profit, men næppe værfterne på længere sigt; forbundet ville sikre beskæftigelsen, og derfor for enhver pris redde værfterne.

I 1975 udsendte Kontaktudvalget en såkaldt "Aktionsplan på værftsområdet", hvor udvalget slår til lyd for, at man i værftsindustrien udnytter de muligheder for omkostningsdæmpning, som septemberforliget gav. ${ }^{33}$ Kontaktudvalget henstiller "... derfor til værftsledelserne og værfternes ansatte, at der optages lokale forhandlinger under hensyntagen til de enkelte værfters behov med henblik på at tilvejebringe et holdbart kalkulationsgrundlag ved tilbudsgivningen".${ }^{34}$ Omkostningsdæmpning og holdbart kalkulationsgrundlag, eller

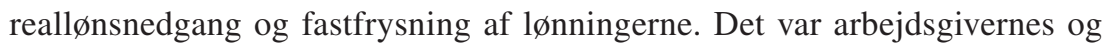
forbundets politik indenfor værftsområdet, som det havde været det talrige gange før, både i 1960'erne og i 1970'erne før krisegennembruddet. Situatio-

33. Septemberforliget, 1975 drejer sig om at afdæmpe, som det hedder i Hensigtserklaringen, stigningstakten i pris-, indtægts- og omkostningsniveau. Relevant i denne sammenhæng er især det afsnit, hvor det hedder, at Folketinget er enig med regeringen om, at hensynet til beskæftigelsen gør det $\varnothing$ nskeligt, at lønændringer i overenskomstperioden alene omfatter de i overenskomsten hjemlede.

34. Handelsministeriets kontaktudvalg vedrørende skibsvarfter: Aktionsplan på værftsområdet; 30 . september 1975 , s. 4. Kontaktudvalget er at betragte som en trepartsforhandling med repræsentation fra de to organisationer og staten. Udvalgets beslutninger gives i form af henstillinger til de respektive parter (værftsarbejdere, værftsledelser og staten). 
nen var imidlertid ændret gennem den voksende industrielle reservearmé og de voksende lokale arbejdskraftreserver; politikken fik det materielle grundlag, som ikke tidligere havde været til stede.

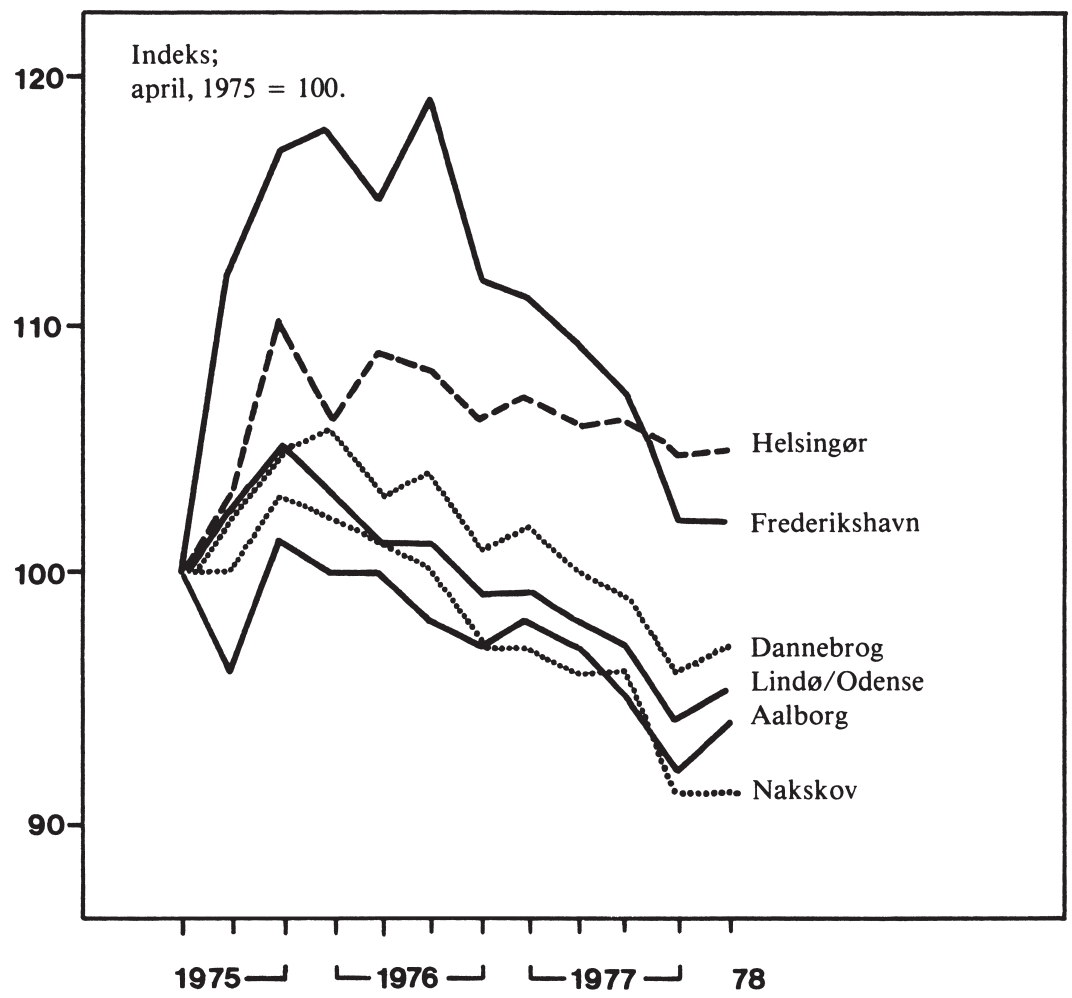

Figur 6. Realtimelønsudviklingen på værfterne; deflateret med forbrugerprisindekset $(1964=100)$. Realtimelønsfortjenesten sat på indeks; april, 1975 = 100. Kilde: Metalarbejderforbundets lønstatistik; diverse årgange.

Værftsarbejderne kæmpede imod det voksende løntryk, som den ligeledes voksende reservearmé medførte. ${ }^{35}$ De forel $\varnothing$ bige resultater af disse kampe kan ses af figur 6, som viser en klart faldende tendens for reallønningerne, omend i forskellig omfang. Figuren siger ikke noget om lønniveauforskelle værfterne imellem, men derimod noget om udviklingstendenserne: alle værf-

35. Begyndelsen af 1975 er præget af usædvanlige mange arbejdskampe på værfterne; i første kvartal forekommer der således strejker på Ålborg Værft, Århus Flydedok (Dannebrog Værft), B\&W, Lindøværftet, Helsingør Værft, Ørskov Stålskibsværft, Nordhavns Værft og Odense Stålskibsværft; 
ters lønninger er sat lig med 100 pr. april 1975; i den foregående periode har lønningerne på værfterne udviklet sig stort set parallelle (men på forskelligt niveau); efter april 1975 udvikler lønningerne sig afgørende forskelligt fra værft til værft.

Som tidligere sagt vil arbejdslønnens bevægelser på de enkelte værfter være et resultat af flere forhold: dels arbejdslønnens generelle bevægelse, og dels svingninger på det lt kale arbejdsmarked og akkordlønsystemernes indretning og satser. Hvis vi ser væk fra arbejdslønnens generelle bevægelse (det kan statistisk gøres ved at udregne arbejdslønnen på værfterne som procenter af hele Metalarbejderforbundets gennemsnitslønninger), viser der sig følgende mønster:

- lønningerne på Nakskov Værft, Lindø/Odense Værfter og B\&W-værftet viser relativt faldende tendenser (kraftigst for Nakskov).

- Aalborg Værft og Dannebrog Værft har lønningerne stort set samme uforandret tendens (d.v.s. samme faldende udviklingstendenser som hele forbundets lønninger).

- Frederikshavn Værfts lønninger udviser først kraftigt relativt stigende og dernæst relativt faldende tendenser.

- Helsingør Værft har arbejdslønnen en relativt stigende tendens.

Dette udviklingsmønster svarer meget nøje til svingningerne i de lokale arbejdsmarkeder og til omfanget af forringelserne af akkordlønsystemerne på de enkelte værfter. Vi skal behandle udviklingen på Nakskov Værft og Lind $\varnothing$ Værft for at se nærmere på situationens muligheder og skranker, samt udviklingens årsager.

\subsection{Nakskov-løsningen}

I 1976 blev der på Nakskov Værft indgået en ny lønaftale til erstatning for det hidtidige akkordlønsystem, som efter de foreliggende oplysninger har været et arbejdstidsstuderet akkordlønsystem.

Formålet med det nye lønsystem blev angivet som: sikring af beskæftigelsen indtil 1980; sikring af nye ordrer, fordi værftet med det nye lønsystem ville blive mere konkurrencedygtig, osv. Imidlertid fik arbejderne ingen reelle ga-

for en række af værfterne er det de første strejker i en række år. Strejkerne drejer sig primært om en kamp mod forringelse af løn- og akkordforhold, men også enkelte afskedigelsessager. Jvf. Tyge Kjar: Beskrivelse af nogle strejker fra de første måneder af 1975 indenfor skibsværftsbranchen, slagteribranchen og den grafisk industri, og omrids af strejkernes baggrund; TEK/SAMGRUNDKURSUS, 1975/76, bd. IV, s. 162 ff. 
rantier. Indtil videre har værftet da heller ikke fået nye ordrer, udover to DSBfærger, som først skal bygges efter aftalens udløb i 1980; værftet har derfor bebudet afskedigelser i oktober 1978 på 800 mand, som vil halvere beskæftigelsen på værftet.

Det nye akkordlønsystem består af to dele: dels en grundløn, som følger Forbundets timelønsoverenskomst, og som er hovedparten af den samlede løn, og dels en fallesbonus. Hovedpunkterne i aftalen er følgende (forkortet): ${ }^{36}$

1. Løn og gager tillades en maksimal stigning på 5\%.

2. Mere end to dyrtidsportioner pr. år og lønstigninger i forbindelse med 1977-overenskomsten vil være værftets risiko. ${ }^{37}$

3. Der indføres en bonusordning, baseret på sparede timer i forhold til de budgetterede for hver enkelt skib; den samlede bonus deles op i to portioner, $50 \%$ til hver part (værftet og alle ansatte).

4. ØK-skibe, som bygges på værftet, giver en specialbonus på én mill. kr. pr. skib, som fordeles mellem samtlige voksne medarbejdere (excl. lærlinge) under følgende forudsætninger:

- opretholdelse af arbejdsro.

- overholdelse af det budgetterede timeprogram for hvert enkelt skib.

- overholdelse af de under 1) og 2) nævnte maksimale løn- og gagestigninger.

Specialbonussen på ØK-skibene fik først virkning fra 1977, medens lønsystemet indførtes med virkning fra ca. 1. april 1976. Aftalen løber fra 1976-79 (incl). Aftalen betyder, at grundlønnen kun må stige med 5\% om året; det betyder i praksis, at løfteparagraffen er sat ud af kraft. Akkordtillægget er ret særpræget, men særdeles kapitalistisk rationelt. Det er i virkeligheden det system, som kontaktudvalget allerede i 1967 foreslog, at værfterne skulle forhandle om indførelsen af.

Da bonusgrundlaget er overholdelse af en samlet byggetid for hvert skib, så måles på denne måde ikke blot arbejdsintensiteten, men også den tid, hvori maskineriet/fixkapitalen anvendes; det skal ikke mindst ses i lyset af relative store investeringer i fixkapitalen i årene 1976-77, som har forskubbet $\varnothing$ konomiseringsgrundlaget; i 1976 og 1977 er investeringerne ca. 10-doblet i forhold til de nærmest foregående år. Fællestillidsmanden Herman Burmeister siger i den

36. Aftale mellem de ansatte på Nakskov Skibsvarft og varftet om lфnudviklingen i årene 1976-77-78-79; 15. januar 1976.

37. Det var ret risikofrit, idet septemberforliget 1975 bl.a. gik ud på at fastholde lønningerne i en treårs periode. 
anledning, at forudsætningen for aftalen er: ${ }^{38} " \ldots$ at værftet investerer betydelige beløb - ca. 20 millioner kroner - i forbedringer af hele produktionsapparatet. Det skal ske for at rationalisere og fremme arbejdsgangen, så man ad den vej gør, hvad der er teknisk muligt for at opnå det $\varnothing$ nskede resultat i retning af hurtigere fremstilling af nybygningerne". Den tekniske arbejdsproduktivitet er da også steget voldsomt i 1976 og 1977, både gennem den tekniske ændring og som er resultat af det nye bonuslønsystem. Det fremgår af tabel 6.

Tabel 6 Stigninger i den tekniske arbejdsproduktivitet på Nakskov Værft; årlige stigninger 1974-1977.

\begin{tabular}{lcccc}
\hline & 1974 & 1975 & 1976 & 1977 \\
Teknisk arbejdsproduktivitet & 0,2 & $-4,2$ & 36,0 & 13,9 \\
\hline
\end{tabular}

Kilde: Nakskov Værfts Beretning og regnskab, diverse årgange.

Èt af formålene med det nye akkordlønsystem kan derfor ses som et spørgsmål om at sikre, at den kraftigt stigende arbejdsintensivering ikke omsættes i lønstigninger, hvad der ville have været tilfældet med det arbejdstidstuderede akkordlønsystem.

Således som akkordlønsystemet er opbygget kan ledelsen frit sænke byggetiden fra skib til skib, og således uden lønmæssige virkninger hæve arbejdsintensiteten fra skib til skib. I lønsystemet er der ikke indbygget kompensation for den fortløbende intensivering af arbejdet; det ville nemlig have forudsat, at det der tidligere var opnået på bonusakkorden for ét skib, blev ført videre som lønstigninger i basislønnen ved det næste skib.

Bonusbetalingen er på 80,- kr. for hver sparet løntime; her får de ansatte 40,- kr. Det betyder følgende sammenhæng mellem lønstigninger og arbejdsintensiveringer udover de fastsatte byggetimer, se tabel 7 .

Tabel 7 skal forstås sådan: hvis der f.eks. spares $5 \%$ på de fastsatte byggetimer, opnås der et bonustillæg i 1976, som svarer til 5,8\%'s timelønstillæg; i 1979 betyder det imidlertid kun en stigning på 4,8\%, da bonustillægget ikke er dyrtidsreguleret. I 1977, hvor der både udbetales bonus og den nævnte ØK-specialbonus, betyder 5\%'s besparelse en timelønsstigning på 9,1\%. Den forholdsvise rimelige sammenhæng mellem produktivitetsstigninger og lønstigninger skal ses i lyset af, at hver skibs timebudget uden tvivl er fastsat således, at det er vanskeligt, måske umuligt, at opnå væsentlige reduktioner i byggetimerne, og

38. Interview med fællestillidsmand Hermann Burmeister i Metal, nr. 5, 1976, s. 11 (vores fremh.). 
Tabel 7 Sammenhængen mellem timelønsstigninger gennem bonustillæg og timebesparelser i forhold til de fastsatte byggetimer.

\begin{tabular}{cccc}
\hline & \multicolumn{3}{c}{ Procentvise timelønsstigninger: } \\
Timebesparelser: & $\begin{array}{c}\text { Bonus } \\
(1976)\end{array}$ & $\begin{array}{c}\text { Bonus } \\
(1979)\end{array}$ & ØK-bonus \\
& 0 & 0 & $(1977)$ \\
-1 & 0 & 0 & 0 \\
0 & 0,1 & 0,1 & 3,5 \\
+1 & 5,8 & 4,8 & 3,6 \\
+5 & 12,3 & 10,1 & 9,1 \\
+10 & & & 15,4 \\
\hline
\end{tabular}

Kilde: Egne beregninger på basis af lønaftalen og Metalarbejderforbundets redegørelse for lønsystemet.

at timebudgettet for hver skib fastsættes uden kompensation eller kontrol fra arbejderside, og uafhængigt af timebudgettet for det foregående skib; endelig skal det ses i lyset af de kraftige stigninger i arbejdsintensiteten (jvf. tabel 6), som uden tvivl fuldt ud er indregnet i timebudgettet.

De profitmæssige virkninger af værftets faldende realløn kan vurderes til 10-15\%'s stigning i værftets profitrate i årene 1976 og 1977. For værftet er timelønsfaldet imidlertid ikke det mest afgørende. Mere afgørende er det derimod, at man kan sikre sig væsentlige stigninger i arbejdsintensiteten uden at skulle betale for det, takket være det nye akkordlønsystem. Afg $\varnothing$ rende er også, at arbejdsintensiveringerne fører til relative besparelser på fixkapitalen. Værftets årsprofitrate stiger i 1976 da også med 233\%, og $i$ 1977 med $486 \%{ }^{39}$

Indførelsen af det nye akkordlønsystem betyder to ting for arbejderne på værftet: en reduktion i lønstigningerne på grund af 5\%'s stigningsgrænsen, og en væsentlig forringet betaling af arbejdet, især fordi abejdsintensiveringen først betales, når et bestemt arbejdsintensitetsniveau er nået (dvs. byggetimerne er overholdt). Om det sidstnævnte siger næstformanden for Centralorganisationen af Metalarbejdere, Charles Hansen: "De ansatte og ledelsen har på utraditionel måde fundet frem til at dele ansvaret for, at virksomheden kan give konkurrencedygtige tilbud på nye ordrer. Aftalen går i hovedtrækkene ud på, at granserne for det bevagelige lønsystem indsnaevres ...". ${ }^{40}$

39. Egne beregninger på basis af værftets regnskaber de respektive år.

40. Interview med Charles Hansen i Arbejdsgiveren, nr. 4, 20.2.1976, s. 3 (vores fremh.). 
I virkeligheden var det bevægelige lønsystems grænser blevet indsnævret tidligere; ikke gennem de "utraditionelle" forhandlinger, men derimod af den voksende lokale reservearmé. Det var en udvikling, som begyndte i 1973, men for alvor tog fart i slutningen af 1975. Fra 1973 til 1975 kommer det til udtryk i relativt stagnerende nominallønninger; optil juli kvartal 1973 havde Nakskovmetalarbejderne 30-50 øre mere i timen end Forbundets provinsafdelinger i gennemsnit; i januar kvartal 1978 lå Nakskov-metalarbejderne 350 øre under. Efter 1975 kommer "indsnævringen af det bevægelige lønsystem" til udtryk gennem faldende reallønninger. ${ }^{41}$

Vi har tidligere sagt, at arbejdslønnen svinger med svingningerne på det lokale arbejdsmarked, og at det bevægelige lønsystem giver første prioritet til det lokale arbejdsmarked og er sårbar overfor lokale indskrænkninger i arbejdsmarkedet, men også at et hævdvundet akkordlønsystem vil kunne fungere som en midlertidig barriere mod en lokalt voksende reserve. Samvirkningen af disse forhold kan belyses med figur $7 .^{42}$

Akkordlønsbarrieren falder med det nye lønsystem i april-maj 1976. Det nye akkordlønsystem forhandles i en periode, hvor beskæftigelsen af metalarbejderne på værftet og i Nakskovafdelingen dykker meget kraftigt, nemlig i januar kvartal 1976. Beskæftigelsen stiger ganske vist i det efterfølgende

41. Reallønnen er her og i det efterfølgende beregnet på følgende måde: nominallønnen (lønoversigtens gennemsnitlige timefortjeneste for akkord- og timelønnede) er deflateret med forbrugerprisindekset, hvor 1964-forbrugerpriser er sat lig med 100. Der er i reallønnen således ikke taget højde for det voksende skattetryk.

42. Om materialet i figur 7 og lignende efterfølgende figurer skal der siges følgende: hovedmaterialet er baseret på Metalarbejderforbundets lønstatistik; hovedmaterialet omfatter således kun (organiserede) metalarbejdere i området og på værftet. Metalarbejderforbundets lønstatistik omfatter tre oplysningskategorier på forskelligt detaljeringsniveau: a) samlet medlemstal, her foreligger der oplysninger for hver lokalafdeling; b) statistiskpligtige medlemmer d.v.s. alle beskæftigede, voksne arbejdere (altså ikke lærlinge), foreligger oplyst for hver lokalafdeling; c) medlemmer med lønoplysninger, d.v.s. det antal medlemmer, fra hvem der faktisk foreligger lønoplysninger; er oplyst for såvel lokalafdeling som for hver fabrik i området. Vi har anvendt oplysningerne vedrørende punkt b og c, samt de til punkt c korresponderende lønoplysninger; det vil bl.a. sige, at opgørelsen af antal beskæftigede metalarbejdere på værftet bygger på oplysninger fra punkt c. Taget for Forbundet som helhed er der imidlertid en temmelig stor forskel mellem antallet af statistisk-pligtige medlemmer og så de medlemmer, som faktisk oplyser deres lønforhold. Efter Forbundets oplysninger til os hænger det især sammen med, at en række mindre arbejdspladser ikke oplyser deres lønforhold. For værfterne, som alle er store og større arbejdspladser skulle dette forhold således ikke spille nogen afgørende rolle for statistikkens anvendelighed. Som udtryk for svingningerne i det lokale arbejdsmarked anvender vi primært beskæftigelsesudviklingen, og ikke arbejdsløshedsprocenterne. Det hænger sammen med, at udviklingen i beskæftigelsen er opgjort efter arbejdssted; den indkalkulerer derfor det eksisterende pendlingsmønster. Falder f.eks. beskæftigelsen i Nakskov Metalafdeling eller på Nakskov Værft vil det - ihvertfald for den korte periode, vi undersøger - betyde, at der er ledige indenfor det hidtidige lokale arbejdsmarked. Arbejdsløshedsprocenter er efter bopæl; det er muligt at få arbejdsløshedsprocenten for mindre enheder end amter, som vi anvender. Grunden til at vi anvender amtsvise oplysninger er, at det regionale arbejdskraftsopland i alle tilfælde omfatter temmelig store geografiske områder, som er langt større end de enkelte byers arbejdsanvisningskontorers områder; arbejdsløshedsprocenterne kan faktisk først anvendes under forudsætning af en undersøgelse af det regionale pendlingsmønster. Det har vi måttet afstå fra. 


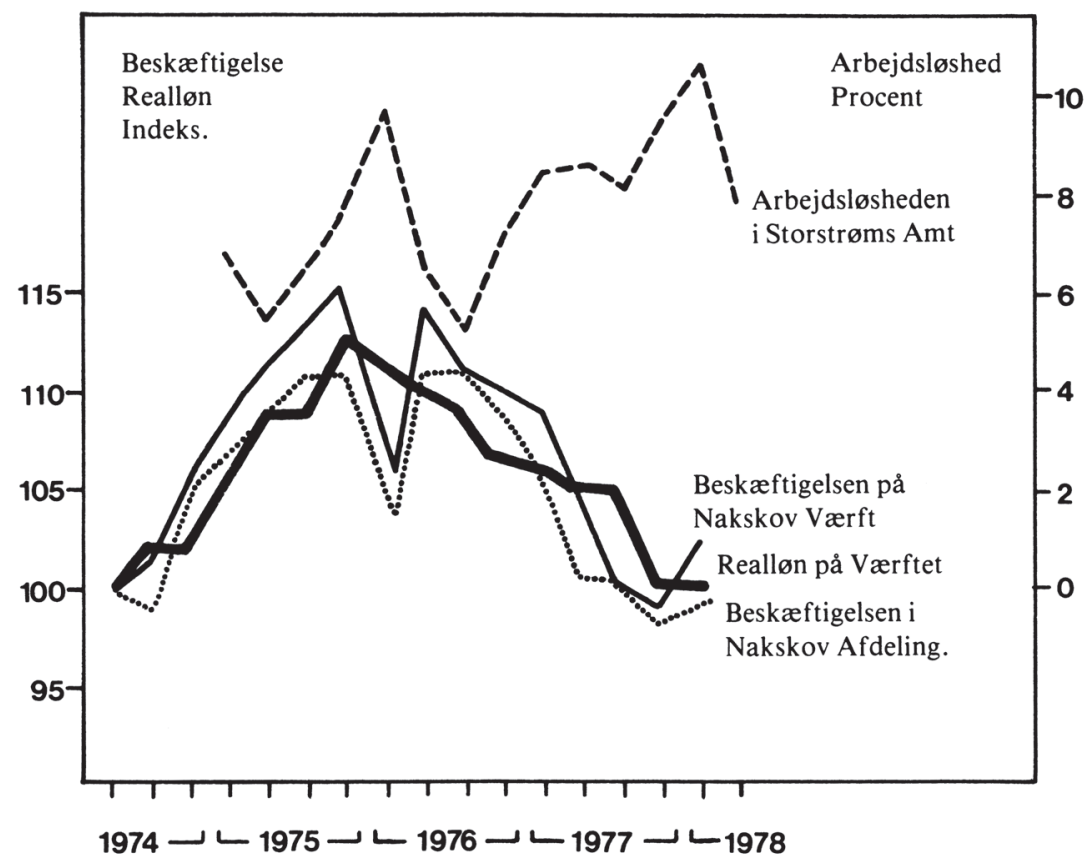

Figur 7. Sammenhæng mellem udviklingen i reallønnen og beskæftigelsen på Nakskov Værft, i Metalarbejderforbundets Nakskovafdeling, samt arbejdsløsheden for metalarbejdere i Storstrøms Amt i perioden april kvartal 1974 - januar kvartal 1978. Indeks april, $1974=100$. Kilde: Metalarbejderforbundets l $\phi n$ oversigter, samt Arbejdsmarkedsstatistik, diverse numre.

kvartal, men falder derefter i hele perioden frem til januar kvartal 1978, hvor den stiger en smule. Med den faldende beskæftigelse bliver det umuligt at opretholde reallønnen; den falder derfor fra oktober kvartal 1975 og frem.

Den afgørende årsag til den direkte sammenhæng mellem beskæftigelsen på værftet og reallønnens udvikling er, at værftet er den dominerende metalarbejdsplads i området. I hele perioden er ca 75-80\% af Nakskov metalafdelingen beskæftiget på værftet; i området er der ikke andre større arbejdspladser; den næststørste er Thrige-Titan, som beskæftiger 50-100 mand i perioden, mens værftet beskæftiger 900-1150 metalarbejdere. Det betyder, at værftets beskæftigelsesudvikling er helt afgørende for den lokale reservearmés størrelse, og derfor også på det tryk, som den udøver på arbejdslønnen. 
Sammenfattende kan siges. For værftskapitalen ser problemstillingen sådan ud: værftet må ændre akkumulationsmønter (dvs. akkumulere intensivt for derigennem at udvikle teknologien) eller lukke. De kapitalistiske betingelser for det intensive akkumulationsmønster er, at arbejdslønnen ikke vokser modsvarende den betydelige vækst i arbejdsproduktiviteten, som et ændret akkumulationsmønster vil medføre. Eller sagt på en anden måde: det hidtidige akkordlønsystem og den styrke, hvormed værftsarbejderne tidligere har været i stand til at opretholde dette lønsystem, er blevet en akkumulationsmæssig hæmsko for værftet. Den voksende lokale reservearmé etablerer derfor værftets nye akkumulationsgrundlag, fordi dens tryk gør det muligt at ændre lønsystemet; i tillæg hertil gør den det også muligt at sænke realtimelønnen.

For værftsarbejderne ser problemstillingen objektivt således ud: hvis værftet ikke skal lukke, hvis beskæftigelsen skal reddes, skal der foretages nyinvesteringer. Betingelserne er indførelse af det nye akkordlønsystem. Investeringerne, som ialt blev på knap 35 mill. kr. i årene 1976 og 1977, ses derfor som en forsikring om, at beskæftigelsen er blevet sikret i for det mindste de næste fire år. ${ }^{43}$

Det er imidlertid ikke tilfceldet på grund af investeringernes virkninger i form af teknologisk frisættelse. Med den tidligere teknologi (og udviklingsgrad i abejdets produktivkraft) har timeforbruget pr. skib været ca. 750.000 arbejdertimer. Den nye teknologi vil efter alt at dømme føre til et timeforbrug pr. skib på ca. 450.000 arbejdertimer. ${ }^{44}$ Denne frisættelsesvirkning kommer ikke på én gang, men vil tage 3-4 år fra de første investeringer i 1976, idet indførelsen af de nye driftsmidler forudsætter modsvarende arbejdsorganisatoriske ændringer, førend fixkapitalinvesteringerne resulterer i en udvikling af arbejdets produktivkraft på et højere niveau. Ligesom det tager nogen tid inden den nye teknologi er fuldt ud arbejdsintensiveret. Ikke desto mindre kan der allerede i 1976 og 1977 konstateres frisættelsesvirkninger (jvf. fig. 7; men jvf. også stigningerne i den tekniske arbejdsproduktivitet i tabel 6).

Den svækkede styrkeposition for værftsarbejderne i Nakskovområdet, som var udgangspunktet for det nye akkordlønsystem, blev for kapitalisten samtidig

43. Sikring af beskæftigelsen har været et meget anvendt argument for Nakskov-løsningen. Imidlertid indeholder aftalen ingen løfte om fortsat beskæftigelse, eller løfte om, at værftsledelsen i aftaleperioden ville sikre de nødvendige ordre (f.eks. fra ØK, værftets ejer).

44. Denne formodning bygger på, at Nakskov Værfts bygger skibe, som er meget lig dem, der bygges på Lind $\varnothing$-værftet, både hvad størrelse og type angår; der kan imidlertid være forskel på udrustning, m.v. Lind $\varnothing$-værftet har den teknologi, som Nakskov Værft er ved at indføre. Lindø-skibene er aftalt til at skulle bygges på i gennemsnit 450.000 timer. 
udgangspunkt for en akkumulation, som fik og efter alt at dømme fortsat vil få de lokale reserver til at svulme yderligere. Det førte og vil fortsat føre til en yderligere svækkelse af værftsarbejderne i området, således som det kommer til udtryk i den faldende realtimeløn.

\subsection{Lindøaftalen}

I begyndelsen af juli 1978 blev der vedtaget en aftale om et nyt lønsystem på Lindøværftet med virkning fra midten af august. (Odenseafdelingen af værftet var ikke taget med i aftalen, fordi afdelingen skulle nedlægges i løbet af efteråret, og produktionen skulle overflyttes til Lindøværftet i Munkebo).

Det nye akkordlønsystem bygger på en fællesakkord, en aftale om samlet timeforbrug pr. skib, og en speciel form for bonusordning. Aftalen, som har mange lighedspunkter med Nakskovaftalen, blev vedtaget efter afstemning blandt alle ansatte arbejdere med et knebent flertal. Forud for denne vedtagelse havde der været en række forhandlinger og afstemninger, som alle havde ført til direkte eller indirekte forkastelse af et lønsystem, som ikke var afgørende forskelligt fra det, som blev vedtaget i sidste runde.

Det nye Lind $\varnothing$ akkordlønsystem erstatter et arbejdstidsstuderet akkordlønsystem. Da et sådant arbejdstidsstuderet akkordlønsystem har været typisk for værftsbranchen i slutningen af 1960'erne og i 1970'erne frem mod krisen, skal vi gennemgå en konkret aftale på Lindø, nemlig aftalen for svejserne.

Det arbejdstidsstuderede akkordlønsystem for svejserne på Lind $\varnothing$ stammer fra midten af 1960'erne, og er ændret i 1969 og i 1972/73. Ændringerne er hovedsageligt gået på ændringer i priskurranterne (dvs. en betalingsfaktor for bestemt mængde ydet arbejde) og på tillægstidsordningerne (se senere), mens selve systemet var uændret. Frem til 1972/73 var priskuranterne i øre pr. meter; i det system, som gjalt fremt til den nye akkordlønaftale i 1978, er priskuranterne angivet i meter pr. minut. Det hidtige akkordlønsystem består af fire dele:

1. Operationstid. Operationstiden er tidsstuderet (arbejdstaktvurderet; baseret på tidsmålinger og tidsforbrug på forskellige arbejdsoperationer). Priskuranterne angives i meter pr. minut for forskellige svejsesømtyper ved forskellige pladetyper. Denne priskurant gælder for al svejsning i alle afdelinger.

2a. Driftsteknisk tillaggstid (angivet i priskuranter). Driftsteknisk tillægstid er afhængig af "forstyrrelser" i produktionsgangen, f.eks. klarg $\varnothing-$ 
ring, ventetid på andre fag, kran, formand, m.v.; hentning af elektroder, værktøj, osv. Den driftstekniske tillægstid er studeret for forskellige produktionssteder (værftet er opdelt i 8 produktionssteder). Tillægstiden er studeret ved hjælp af stikprøver, og kan variere meget fra produktionssted.

2b. U-kurant tillagstid. U-kurant tillægstid er tillæg for at udføre arbejde på sektioner, hvor der på grund af dårlig tilpasning, fejl, osv. ikke kan arbejdes efter priskuranterne. Ved bygning af en ny skibstype i serie blev det første skibs gennemsnitlige antal tillægstimer med et tillæg på 1-2\% anvendt som tillægstimer for de efterfølgende skibe i serien. På denne måde sparede værftet kontrollen og opmålingen, mens arbejderne omvendt fik en "søsterskibseffekt" (det vender vi tilbage til senere).

3. Akkordtillacg. Akkordtillæg er tillæg for svejsning i små rum, i liggende stilling, osv. Akkordtillægget udgør 5-10\%'s tillæg til akkordtiderne. (Foruden dette findes der også tillæg for svejsning i lukkede tanke - det såkaldte genetillæg - som er en fast pris i $\varnothing$ re pr. time).

4. Ventetid. Ventetid drejer sig specielt om venten på sikkerhedsudstyr, f.eks. udsugning. Ventetiden aflønnes med klubbens akkordgennemsnit.

Selve akkorderne (punkterne 1, 2a, 3) er forudskrevne, dvs. arbejderne får en seddel fra produktionsplanlæggerne med angivelse af antal meter svejses $ø \mathrm{~m}$ af forskellig type, samt tid i minutter. Akkorderne blev normalt udstukket for en dags arbejde. I priskurantaftalen findes omregningstabeller fra minutter til $\emptyset$ re; omregningerne kunne løbende forhandles efter løfteparagraffen; deres opsigelsesfrist var på to måneder. Under opsigelsen blev arbejderne aflønnet på det hidtidige akkordlønsgennemsnit minus $15 \%$. I priskurantaftalerne har der været bestemmelser vedrørende arbejdets kvalitet - både før og efter svejsningen, men det har varieret alt efter hvor stram, kontrollen har været. Et i princippet lignende akkordlønsystem har også været anvendt for skibsbyggerne, men også for andre arbejdergrupper på værftet. ${ }^{45}$

Det arbejdstidsstuderede akkordlønsystem er af værftets arbejdere blevet betragtet som favorabel af flere grunde. Lønsystemet var relativ kompleks og kontrollen var i praksis enten umulig eller mindre stram; det har været mulig at

45. For skibsbyggerne har operationstiden ikke været fastlagt som en forudskreven akkord, men som en aftale akkord, d.v.s. akkorden aftales medens produktionen foregår. Som regel gøres et skibs sektioner halvfærdig, hvorefter akkorden aftales. 
få forholdsvise gode lønninger uden voldsom intensivering af arbejdet. ${ }^{46}$ Over hele perioden, men især tidligere, har klubberne kunnet føre en effektiv akkordloftspolitik, som har hindret, at akkordlønsystemet er blevet udhulet og tempoet af den grund tvunget i vejret. Efter opsigelsen af det hidtidige akkordlønsystem, men inden indførelsen af det nye, vedtog skibsbyggerne "frit slag" i forhold til lofterne. For mange betød det mere end $5 \mathrm{kr}$. ekstra i timen, som viser at klubbernes akkordloftpolitik har været effektiv.

Den nye lønaftale dækker i første omgang bygningen af 6 cargolineskibe og 4 supplyskibe, alle til A. P. Møllerkoncernen. Sidenhen er aftalen blevet suppleret med en aftale, som gælder for bygningen af yderligere 4 containerskibe. ${ }^{47}$ Hovedindholdet i aftalen er følgende:

1. Hvert skib bygges til et fastsat timetal (f.eks. følgende for de 6 cargolineskibe: 450.000 timer i direkte byggetimer $+13 \%$ i indirekte timer, altsammen i gennemsnit).

2. Værftet opdeles i tre bonusområder (hal, udvendige planer; dok, stål og malehaller; udrustning og værksteder). Indenfor hvert bonusområde findes der en fællesakkord, som fremkommer ved at hvert område hensætter $12 \%$ af områdets samlede timer i en fællespulje.

3. De akkordlønnede får en forskudsbetaling/mindste garantibetaling, som er de enkelte klubbers akkordgennemsnit i april kvartal 1978 minus 1,75 kr., hvis klubbens gennemsnit er over 25,- kr., og minus 1,50 kr., hvis klubbens aprilgennemsnit var under. (Jvf. akkordtimelønnen i tabel 3 tidligere i artiklen).

4. For hver arbejder består lønnen af tre dele: a) dyrtidstillægget på ca. 17,- kr; b) forskudsbetalingen/garantibetalingen; og c) en bonus, som både kan være negativ eller positive.

46. Sammenhængen skal ses som følger: akkordlønsystemet har efter de foreliggende oplysninger ikke virket kraftigt arbejdsintensiverende på den ene side, og på den anden side har værftet i perioden op til krisen for det meste været i mandskabsmangel; det lokale arbejdsmarked har været et sælgers marked, som har muliggjort gode priskuranter, m.v. Det spiller også en rolle, at det tidligere akkordlønsystem til trods for sit pålydende har fungeret mere eller mindre udpræget som et slumpakkordsystem, fordi arbejderne tidligere har været i den styrkemæssige position, at de kunne afslå at udføre et arbejde efter f.eks. den forudskrevne akkord, hvis der ikke var penge nok i det; der blev så givet tillæg på forskellig måde, som var i modstrid med det eksisterende akkordlønssystems funktionsgrundlag. I oktober kvartal lå lønningerne på værftet f.eks. 7,7\% over Forbundets landsgennemsnit. Det var næppe selve akkordlønsystemet, som gav de gode lønninger, men derimod udviklingen på det lokale arbejdsmarked.

47. Disse skibe er også til A.P. Møllerkoncernen, som ejer værftet. Aftalen er ikke vedtaget ved urafstemning, men indgået mellem klubbestyrelse, tillidsmænd og værftsledelse. Med disse skibe har værftet en ordebeholdning på 14 skibe. Forudsætningen for aftalen om de fire containerskibe er, at staten går med til en forbedring af de eksisterende statsfinansieringsordninger, altså rederiets finansiering af skibskøb fra eget værft; det sker under henvisning til, at der ellers vil ske afskedigelser på værftet. Oplysningerne stammer fra Aktuelt, 1.12.78, s. 19. 
5. I lønsystemet findes der to bonuspuljer. Dels den tidligere nævnte fællespulje for hver af de tre bonusområder, og dels en branche- eller klubbonus. Hvis et bonusområde sparer optil $12 \%$ af de fastlagte byggetimer, udbetales de sparede timer ganget med bonusområdets gennemsnitlige basisløn; denne bonus udbetales ligeligt til alle indenfor samme bonusområde. Hvis en klub eller branche sparer mere end $12 \%$ af timerne får den en bonus efter samme retningslinier som ved fællesbonussen, dog kan denne bonus aldrig blive større end $50 \varnothing$ re pr. ydet arbejdstime; den resterende besparelse indgår dernæst i fællespuljen for det bonusområde, som branchen/klubben tilhører. Hvis byggetiden overskrides afgiver de akkordlønnede et beløb, som svarer til timeoverskridelsen ganget med bonusområdets gennemsnitlige basisløn. Der kan dog kun blive tale om at afgive et beløb på 1,75 kr. (eller 1,50 kr. - afhængig af overskridelsens $\mathrm{s} \varnothing$ rrelse) pr. ydet arbejdstime.

Basistimelønnen er baseret på akkordtimefortjenesten i april kvartal; ved påbegyndelse af et nyt skib lægges der et $\varnothing$ rebel $\varnothing \mathrm{b}$ (fra 0 til $35 \varnothing \mathrm{re}$, afhængig af klub og tidspunkt) til timefortjenesten i april kvartal. Derved fremkommer der løbende en ny basisløn, ganske vist med meget beskedne stigninger. Tillidsmændene havde krævet, at basislønnen for hvert nyt skib skulle være gennemsnitstimefortjenesten (garantibetaling + opnået bonus) ved det foregående skib. Det ville betyde, at det der tidligere var blevet opnået på bonusakkorden blev ført videre som lønstigning i basislønnen ved bygning af det efterfølgende skib. Ledelsen ville netop med sit system begranse denne virkning. De faste $\varnothing$ rebel $\varnothing \mathrm{b}$ betyder, at løfteparagraffen i praksis er sat ud af kraft; dog ikke helt på samme måde som ved Nakskov-løsningen. Her var øretillægget fastsat frem til 1980; ved Lindøaftalen er øretillægget fastsat for de 10 nybygninger, som ganske vist skal bygges frem til og med 1979, men ved forhandling om yderligere skibsbygninger indenfor perioden, forhandles også øretillægget, hvad der ikke var tilfældet for Nakskov. ${ }^{48}$

Selvom der er tale om en fællesakkord i det nye lønsystem, vil systemet uden tvivl virke opsplittende på arbejderne, fordi der i fællesakkordsystemet er indbygget en branche- eller klubakkord, men især fordi fællespuljens samlede størrelse er afhængig af, at alle indenfor bonusområdet overholder de byggetimer, som på forhånd er afsat til deres klub. Eller sagt på en anden måde: det tidligere arbejdsstuderede akkordlønsystem fik værftet til at foretage en række

48. Øretillægget i Lindøaftalen betyder på årsbasis følgende stigninger i basislønnen: for de lavest akkordlønnede en stigning på 2,1\% og for de højest akkordlønnede en stigning på 1,7\%. For de timelønnede, som er få og meget lavtlønnede, betyder det en stigning på ca. 5\% på årsbasis. 
kontrolopmålinger af mængden af det udførte arbejde. Nu er kontrollen helt tvunget over i arbejdernes egne hænder.

Ved en vurdering af lønsystemet set fra arbejderside er det afgørende, hvilken sammenhæng der er mellem produktivitet og $l \phi n$, netop fordi der er tale om et akkordlønsystem. Det nye lønsystem fører til produktivitetsstigninger på to måder, hvor den ene ikke giver stigninger i lønnen, mens den anden $g \varnothing r$ det.

(1) For det første sker der uden tvivl en produktivitetsstigning gennem fastlæggelsen af timerammen, fordi den efter alt at dømme er snævrere end det hidtidige timeforbrug for et skib. Den produktivitetsstigning, som følger af en snævrere ramme, betaler værftet intet for. Hvis der produceres til den fastsatte timeramme vil der endog være tale om en lønreduktion på 6,5\% i forhold til den hidtidige akkordtimefortjeneste (jvf. tabel 9 i det efterfølgende). Vi er ikke i stand til at belyse den nøjagtige produktivitetsstigning ved den nu fastsatte timeramme, men vi skal sandsynliggøre dens omfang. I forhandlingerne om byggetimerne for de seks cargolineskibe havde fællesklubben stillet et timekrav, som var knap $11 \%$ højere end det endelige resultat for cargolineskibene. Tog man forsigtigvis det udgangspunkt, at fællesklubbens krav var udtryk for, at arbejdet med deres timeramme ville blive udført med den hidtidige intensitet, så var slutresultatet udtryk for en produktivitetsstigning på knap $10 \%$.

Hvis der bygges skibe i serie, vil en del af arbejdsprocesserne kunne udføres hurtigere ved det andet, tredie, o.s.v. skib; den såkaldte søsterskibseffekt. Aftalen om den gennemsnitlige timeramme betyder, at søsterskibseffekten er indkalkuleret. I det tidligere lønsystem (jvf. den tidligere beskrivelse) fik arbejderne en væsentlig del af søsterskibseffekten, fordi f.eks. svejsernes ukurante tillægstid og skibsbyggernes aftaleakkord blev aftalt med udgangspunkt i det første skib i en serie, og altså ikke som et gennemsnit af seriens skibe. Som sagt vil søsterskibseffekten være indregnet i timerammegennemsnittet. I forbindelse med aftalen har værftet regnet med følgende søsterskibseffekter for de 6 cargolineskibe og de 4 supplybåde:

Tabel 8 Søsterskibseffekten ved serieproduktion af 6 cargolineskibe og 4 supplybåde. Byggetiden for de efterfølgende skibe er i procent af første skib.

\begin{tabular}{lcccccc}
\hline & 1.skib & 2. skib & 3.skib & 4.skib & 5.skib & 6.skib \\
Cargolineskibe: & 100 & 92 & 86 & 82 & 80 & 78 \\
Supplybåde: & 100 & 96 & 92 & 88 & - & - \\
\hline
\end{tabular}


Tog vi - igen forsigtigvis - det udgangspunkt, at byggetimerne for seriens første skib var et udtryk for den hidtidige gennemsnitlige intensitet, bliver resultatet af en indregning af søsterskibseffekten i timerammen, at produktiviteten af den grund vil stige med knap $14 \%$.

Produktivitetsstigning gennem indsnævring af timerammen på $10-14 \%$ er næppe urealistisk. Måske har den været større; der gik nemlig ikke lang tid efter indførelsen af det nye lønsystem, inden det viste sig, at timerammen især for skibsbyggerne var urealistisk lavt sat, så lavt sat, at ledelsen - til trods for aftalens ordlyd og med fare for at hele systemet kunne bryde sammen - måtte gå med til genforhandlinger af timerammen for visse faggrupper. Produktivitetsstigninger ved indsnævringen af timerammen betaler værftet som sagt ikke en $\varnothing$ re for.

(2) For det andet sker der produktivitetsstigninger, hvis der sker besparelser på timerammen; disse produktivitetsstigninger medfører stigninger i den gennemsnitlige timefortjeneste. Hvor meget der er tale om ses af tabel 9.

\section{Tabel 9 Sammenhæng mellem timelønsstigninger gennem bonustillæg og timebesparelser i forhold til de fastsatte byggetimer.}

\begin{tabular}{cc}
\hline Timebesparelser: & $\begin{array}{c}\text { Lønnen procentvis } \\
\text { over basislønnen: }\end{array}$ \\
-5 & $-11,2$ \\
0 & $-6,5$ \\
+5 & $-1,2$ \\
+10 & $+4,6$ \\
+15 & $+11,2$ \\
+20 & $+18,5$ \\
\hline
\end{tabular}

Kilde: Beregninger på basis af Aftale, nr. 78.LL.03. Sammenhængen mellem produktiviteten og lønstigninger vil variere efter klubbens gennemsnitlige akkordtimefortjeneste i april kvartal. Her er der taget udgangspunkt i en klub, som ligger midt imellem.

Af tabellen fremgår det, at hvis arbejderne skal opnå den hidtidige timefortjeneste, skal der produceres med en timebesparelse i forhold til rammen på mellem 5-10\%. En sådan produktivitetsforøgelse vil give samme nominalløn som hidtil; hvis reallønnen skal kunne opretholdes, skal timebesparelsen skønsmæssigt ligge i nærheden af de $15 \%$.

Selvom lønsystemet er baseret på de samme principper som Nakskov-løsningen, er det for Lindøværftet tale om et klart ringere forhold mellem timeløn og produktivitetsstigning i forhold til timerammen. Des ses af figur 8 . 


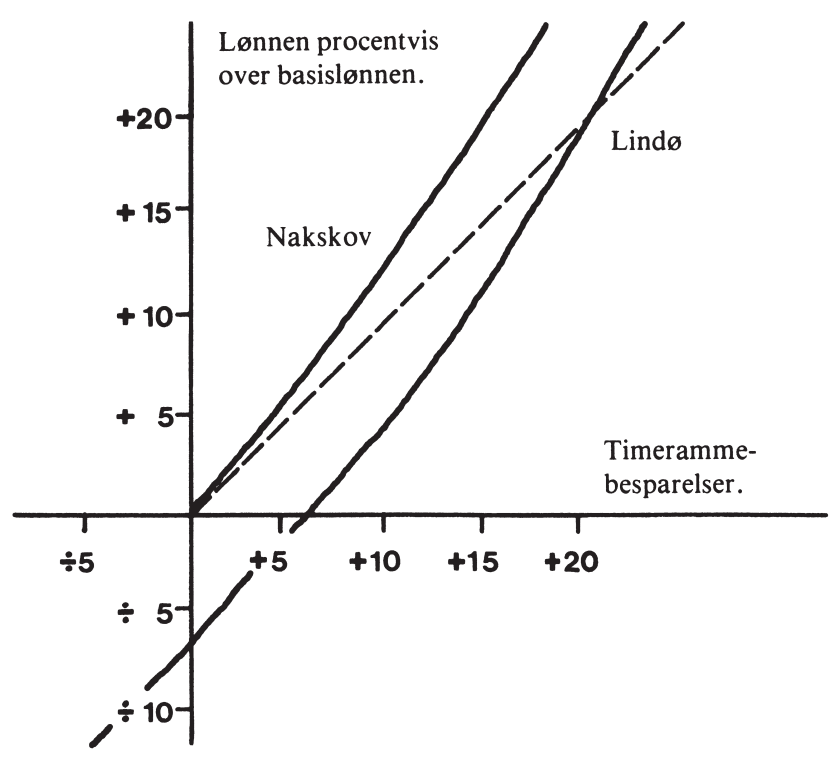

Figur 8. Forholdet mellem timelønsstigninger gennem bonustillæg og timebesparelser i forhold til de fastsatte byggetimer for henholdsvis Nakskov Værft og Lindøværftet.

Af figuren fremgår det, at der er samme forhold mellem produktivitetsstigning og løn på de to værfter (kurverne har omtrent samme hældning), men også at lønudgangspunktet for Lind $\varnothing$-lønsystemet er indbygget en negativ bonusordning, hvis der ikke bygges indenfor den fastsatte ramme, hvad der ikke er tilfældet for Nakskov-løsningen.

Sammenfattende om forholdet løn og produktivitet: hvis påvisningen af produktivitetsstigninger i forbindelse med indsnævringen af timerammen er korrekt, betyder det, at arbejdstempoet skal forøges med ca: 25-29\%, hvis reallønnen skal kunne sikres med det nye lønsystem. ${ }^{49}$

Hovedårsagen til det for arbejderne så dårlige lønsystem må ses i udviklingen på det lokale arbejdsmarked, hvor den afgørende tendens er en faldende beskæftigelse på Lindøværftet. Det fremgår af figur 9.

Det mest karakteristiske er den faldende beskæftigelse for metalarbejdere på Odense/Lindø Værft. På værftets Odenseafdeling er metalarbejdernes beskæftigelse stort set uforandret i hele perioden. Det er på værftets Lindøafdeling, at beskæftigelsen falder. Her sker fyringerne stort set blandt de to største ar-

49. Selvom tillidsmændene på et forholdsvis tidligt tidspunkt var blevet enig med værftet om det nye lønsystem, har de dog stillet en række krav, som - hvis de var blevet gennemført - ville have givet et betydeligt bedre forhold mellem produktivitet og løn; som altså bedre ville kunne have sikret reallønnen, samt have løst en række konkrete utilfredsheder med det eksisterende lønsystem. 


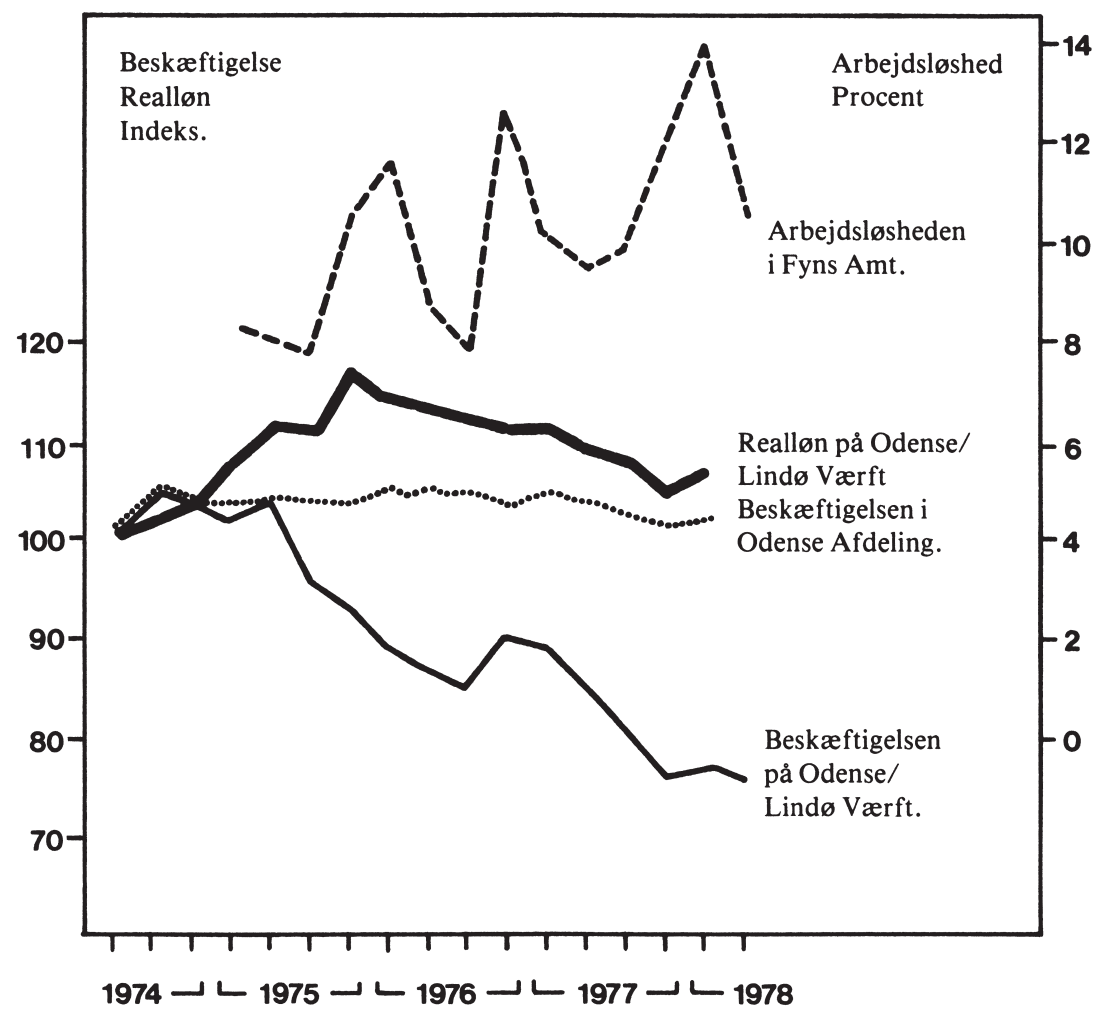

Figur 9. Sammenhæng mellem udviklingen i reallønnen og beskæftigelsen på Odense/Lindø Værft, i Metalarbejderforbundets Odenseafdeling, samt arbejdsløsheden for metalarbejdere i Fyns Amt i perioden april kvartal 1974 - april kvartal 1978. Indeks april, $1974=100$. Kilde: Metalarbejderforbundets lonoversigter, samt Arbejdsmarkedsstatistik, diverse numre.

bejdergrupper, svejsere og skibsbyggere. Over tre år - fra april kvartal 1975 til april kvartal 1978 - falder svejsernes beskaeftigelse med 44\%, og skibsbyggernes med $39 \% .^{50}$ Fyringerne af svejsere og skibsbyggere kom i to bølger. Den første fra juli kvartal 1975 til og med juli kvartal 1976. Den anden fra april kvartal 1977 og frem til nu. (Efter figur 9 stabiliseres beskæftigelsen på værftet ganske vist hen mod udgangen af 1977, men det hænger sammen med $\varnothing$ get ansættelse i udrustningsafdelingen). På figur 9 ses det også, at reallønnen på Odense/Lind $\varnothing$ Værft falder stort set med den faldende beskæftigelse af svejsere og skibsbyggere, som iøvrigt hører til værftets traditionelt set mest højtlønnede. har udgjort ca. 62\% af metalarbejderne på Lindø-værftet i 1975, reduceres til at omfatte 47\% i 1978. 
Men i modsætning til Nakskov Værft fører værftets faldende beskæftigelse ikke til, at værftsledelsen umiddelbart kan fremtvinge et mere intensiverende akkordlønsystem; det sker som bekendt først i midten af 1978. Denne forskudte udvikling hænger især sammen med, at arbejdsmarkedet for metalarbejdere i Odenseområdet er mere sammensat end i f.eks. Nakskovområdet. Det skal vi se nærmere på.

LindøOdense Værftet er langt den største metalarbejdsplads i området, men dog ikke så dominerende som Nakskov Værft er det i Nakskovområdet. I 1974 var ca. $42 \%$ af metalarbejderne i Odenseafdelingen ansat på værftet; denne procent er faldet til ca. 31 i 1978. De to næststørste metalarbejderpladser er Thrige-Titan og Haustrup, som hver beskæftiger 4-5\% af metalarbejderne i Odenseafdelingen. I betragtning af, at værftet var og stadig er en så dominerende arbejdsplads i området, vil afskedigelser af den størrelsesorden, som der er tale om i de to fyringsbølger i årene 1975-78, samtidigt dominere udviklingen på det lokale arbejdsmarked. Værftets frisættelser vil omgående få arbejdsmarkedets reserver til at vokse, med mindre den frisatte arbejdskraft kan opsuges på andre fabrikker.

Men hvor kan den frisatte svejser eller skibsbygger finde beskæftigelse: som svejser eller skibsbygger er der stort set ikke andre beskæftigelsesmuligheder på Fyn og i området på den anden side af Lillebælt. ${ }^{51}$ Derfor vil en frisættelse af svejsere og skibsbyggere umiddelbart udøve et tryk på arbejdslønnen for de beskæftigede svejsere og skibsbyggere. Dette tryk vil i første omgang kunne begrænses af den barriere, som et eksisterende akkordlønsystem og de aftale akkordtariffer udgør. Løntrykket vil derfor i første omgang vise sig som relativt forringede akkordtariffer; dvs. værftsarbejderne vil ikke være i stand til at gennemtvinge forbedringer af tarifferne, svarende til inflationens udhulning af lønnen. Dette rammer ikke blot svejsere og skibsbyggere, men alle værftets ansatte i kraft af svejsernes og skibsbyggernes hidtidige dominerende stilling, både antalsmæssigt, organisatorisk og lønmæssigt. Det er da også tilfældet for reallønsudviklingen i begyndelsen af 1976 og frem til det nye lønsystem i august 1978.

Det er naturligvis kvalifikationsmæssigt ikke udelukket, at de frisatte svejsere og skibsbyggere - om ikke umiddelbart, så dog efterhånden - kan finde beskæftigelse ved andet metalarbejde. I såfald vil reservearméens tryk på grund af de værftsfrisatte reduceres. Det er faktisk tilfældet frem til begyndelsen af 1977. I værftets naturlige arbejdskraftopland vokser antallet af metalarbejderpladser

51. For skibsbyggerne findes kun Svendborg Værft, hvor knap 100 mand er ansat, og hvor der ingen udvidelse finder sted; tværtimod. For svejserne findes der knap 200 egentlige svejsearbejdspladser i hele området udenfor Lindø/Odense Værft, og her kan der heller ikke spores ekspansionstendenser. 
med knap 1.200 mand fra 1974 til og med 1976. ${ }^{52}$ Denne vækst kommer samtidig med værftets første fyringsbølge, som kan have reduceret frisættelsernes løntrykkende virkninger så meget, at værftsledelsen ikke har kunnet spekulere $\mathrm{i}$ indførelsen af et mere arbejdsintensiverende akkordlønsystem. Anderledes forholder det sig med anden fyringsbølge; her er antallet af metalarbejdspladser stagnerende i værftets arbejdskraftopland, og faldende i Odenseafdelingen. Hertil kommer, at det samlede lokale arbejdsmarked ikke har været tilstrækkelig ekspansiv i forhold til nettotilgangen af metalarbejdere; det ses af arbejdsløsheden for metalarbejdere i Fyns Amt på figur 9. Arbejdsløsheden udviser en stadig stigende tendens.

Disse omstændigheder har uden tvivl svækket Lindøværftsarbejdernes styrkeposition så meget, at værftsledelsen i slutningen af 1977 kunne planlægge og i foråret kunne forhandle om et mere arbejdsintensiverende akkordlønsystem med udsigt til, at det skulle lykkes at få det gennemført. ${ }^{53}$

Vi skal afslutningsvis behandle de sandsynlige profitmassige virkninger af det nye akkordlønsystem. Det nye lønsystem har den egenskab, at uanset byggetid (samlet timeforbrug) vil den samlede lønsum pr. skib være meget nær den samme. Det er en følge af det fastsatte forhold mellem produktivitetsstigninger og stigninger i timelønsfortjenesten. Arbejdes der hurtigt, tjenes der mere i timen, men i kortere tidsrum; arbejdes der langsomt, tjenes der mindre i timen, men over længere tidsrum; den samlede lønsum bliver stort set den samme. Det betyder, at løndelen af det enkelte skibs kostpris vil være den samme, uanset om der f.eks. bygges med $10 \%$ under eller $20 \%$ over den fastsatte byggeramme for hvert skib. Når byggerammen er fastsat, vil lønandelen af det enkelte skibs kostpris altså være uafhængig af den produktivitet, som der arbejdes med i forhold til timerammen (altså den produktivitet, som fremkommer ved besparelser på timerammen). Det er lønsystemer med denne egenskab, som Handelsministeriets kontaktudvalg - som tidligere nævnt - har efterlyst, både i 1967 og i 1975. I 1967 hed det” ... aftale med et værfts

52. Det vil sige metalarbejdspladser i følgende afdelinger af Metalarbejderforbundet: Assens, Fredericia, Fåborg, Kerteminde, Kolding, Middelfart, Nyborg, Odense, Ringe og Svendborg. I 1976 er der ialt knap 13.700 metalarbejdspladser i området; heraf 7.300 i Odenseafdelingen, 6.400 i de $\emptyset$ vrige nævnte afdelinger. Af Odenseafdelingens 7.300 findes de knap 2.600 på Odense/Lindø Værftet. Jvf. Metalarbejderforbundets lønoversigter, diverse numre.

53. Det lykkedes ikke i første omgang; sidst på foråret 1978 afviste klubberne en aftale, som ligner den nugældende, og som fællesklubben havde indgået med ledelsen. Det lykkedes heller ikke i anden omgang; da faldt aftalen ved en urafstemning med 1307 stemmer imod og 1301 for. Først i tredie omgang lykkedes det at få aftalen igennem med en forholdsvis lille majoritet. Til belysning af den ændrede situation for værftsarbejderne kan nævnes, at svejserne i april 1975 kunne aktionere på at opsige det gældende akkordlønsystem, jvf. beskrivelse heraf i Tyge Kjar: Beskrivelse af nogle strejker..., op.cit. 
arbejdere eller med grupper af arbejdere om de granser for timetal og samlet lфnsum, indenfor hvilken det pågældende arbejde må holdes"; i 1975 hed det "... optages lokale forhandlinger (I) med henblik på at tilvejebringe et holdbart kalkulationsgrundlag ved tilbudsgivningen" med slet skjult adresse til lønforhandlingerne (hvad forhandles ellers lokalt)? ${ }^{54}$

Lønsystemer af denne type forudsætter imidlertid bestemte typer af akkumulationsproblemer for værfterne; enten fordi man, som i Nakskov Værfts tilfælde, skal have fjernet den hidtidige sammenhæng mellem produktivitet og løn på grund af kraftige stigninger i arbejdsproduktiviteten som følge af udvikling af arbejdets produktivkraft, eller fordi man, som i Lind $\varnothing$ Værfts tilfælde, skal have løst nogle problemer med et alt for stort fixkapitalanlæg.

Lind $\varnothing$ værftsledelsen angiver - omend kun indirekte - akkumulationsproblemernes art i årsberetningen fra 1977. Her hedder det: "Overgangen fra bygning af store tankskibe til mindre skibe ... har indebåret forskellige alvorlige problemer, som har givet sig udtryk i større øget timeforbrug og andre produktionsmæssige besværligheder, som har været yderst kostbare". ${ }^{55}$ Statistisk kan det være vanskeligt at illustrere problemets omfang, men noget kan der dog siges. Af tabel 10 fremgår det, at Lindø-værftets produktivitetsstigninger i 1976 ikke følger trop med værftsindustriens stigninger. Det samme er sandsynligvis også tilfældet i 1977.

\section{Tabel 10 Produktivitetstigninger i værftsindustrien og på Lindø Værft; $1975=100$.}

\begin{tabular}{lcrrc}
\hline & 1974 & 1975 & 1976 & 1977 \\
Lind $\varnothing /$ Odense Værft & $*$ & 100 & 101 & 104 \\
Værftsindustrien & 93 & 100 & 110 & $*$ \\
\hline
\end{tabular}

* Oplysninger foreligger ikke. Kilde: Værftets regnskaber og Industriel udvikling, op.cit., bd. II.

Overgangen fra bygningen af supertankere på over 300.000 tdw til skibe helt ned til 10.000 tdw begynder i 1976, fortsættes i 1977, hvor den sidste supertanker afleveres fra værftet; i 1978 bygges der kun mindre skibe. Ved bygningen af supertankere var værftets afgørende profitproduktionsmetode $\varnothing$ konomisering med fixkapitalen og med den flydende konstante kapital. Det vil sige kortest 
mulig produktionstid, det formindskede den relative størrelse af udlægget til råvarerne, og det gjorde det muligt at udnytte det forhåndenværende produktionsanlæg mest muligt. Økonomiseringen med den konstante kapital skete gennem intensiveringen af arbejdet; jo større arbejdsintensitet, jo mere $\varnothing$ konomisk anvendelse af den konstante kapital. I denne sammenhæng blev økonomiseringen med den variable kapital af underordnet betydning. Værftsledelsen var velvidende om, at det arbejdsstuderede akkordlønsystem ikke fungerede efter sit pålydende, men derimod - som tidligere nævnt - som et slumpakkordsystem; den ekstrafortjeneste, som arbejderne kunne skaffe sig på denne måde var uden betydning i forhold til de profitmæssige gevinster, som kortest mulig produktionstid kunne skaffe værftet.

Overgangen til bygning af de mindre skibe medførte i det mindste tre ting for værftet: 1) delvis braklægning af dele af den fixe kapital i form af reduceret kapacitetsudnyttelse; kapaciteten i svejsehallerne, især i haller med de lige sektioner, men også i dokken, var alt for stor i forhold til de mindre skibe, hvor udrustningen og de skæve (buede) sektioner produktionsmæssigt udgør en forholdsvis større del; her findes én af hovedårsagen til frisættelse af skibsbyggere og svejsere (især den anden fyringsbølge; den første fyringsbølge hang sammen med udviklingen af svejseudstyret; opholdet mellem de to fyringsbølger hang sammen med omstillingsvanskelighederne). 2) Arbejdsorganisatoriske ændringer; de enkelte afdelingers kapacitet og arbejdsorganisation var tilpasset bygningen af supertankere; arbejdsorganisationen blev ændret i overensstemmelse med bygningen af de mindre skibe; en del af de arbejdsorganisatoriske ændringer er nedfældet i lønaftalen. 3) Det eksisterende akkordlønsystem var gennem de ændringer, som i tidens løb stiltiende havde fundet sted, en hindring for et skift i $\varnothing$ konomiseringsgrundlaget. I en situation med delvis braklagt fixkapital mister $\varnothing$ konomiseringen med den konstante kapital delvis sin kapitalistiske betydning. Værftet må satse på andre profitproduktionsmetoder. Her får den variable kapital første prioritet.

Det nye akkordlønsystem griber ind i forhold til alle tre nævnte ændringer. F.eks. betyder fastlæggelse af timerammer ikke blot pr. skib, men for hver afdeling og klub, at det vil være muligt at sikre en kapacitetstilpasning mellem produktionsprocessens enkelte dele gennem differentierede intensiveringer af arbejdet.

Den omstændighed, at det nye akkordlønsystem medfører, at den samlede lønsum pr. skib stort set vil være den samme, uanset hvilken arbejdsintensitet, der arbejdes med, er ikke et udtryk for, at værftet ikke satser på intensiveringen af arbejdet; det er derimod et udtryk for, at der med det nye lønsystem ikke betales en merpris for den arbejdsmængde, som udføres med højere intensitet. Lønnen varierer kun med den ydede arbejdsmangde, og er gjort uafhængig af gevinsten ved fixkapitaløkonomiseringen. Det er det klareste udtryk for, at det 
nye lønsystem skifter $\varnothing$ konomiseringsgrundlag fra den konstante kapital til den variable. Gennem fastlæggelsen af timerammerne sikrer værftet sig i tilgift en løbende intensivering af arbejdet.

Der er ingen tvivl om, at når den omtalte omstillingsproces er ført til ende, vil det betyde yderligere frisættelser af arbejdskraften, ikke på grund af udviklingen af arbejdets produktivkraft, men som en følge af intensiveringen, d.v.s. når værftet har overvundet $\sin$ "... større $\varnothing$ get timeforbrug og andre produktionsmæssige besværligheder", sådan som værftets aktuelle akkumulationsproblemer formuleres i det tidligere anførte citat fra beretningen i 1977.

Sammenfattende om udviklingen kan siges: omstillingen fra produktion af supertankere til mindre skibe fører i første omgang til afskedigelser (især den anden fyringsbølge) som sammen med de tidligere afskedigelser og i kraft af værftets dominerende stilling på det fynske arbejdsmarked fører til en sådan svækkelse af værftsarbejdernes position, at den hidtidige barriere mod den lokale reservearmés tryk - det tidligere lønsystem - falder, og erstattes af et nyt lønsystem, som kan accelere omstillingsprocessen, og dermed uden tvivl vil forværre situationen for de fynske værftsarbejdere.

I værftsarbejdernes stillingtagen til indførelsen af det nye lønsystem har en trussel om lukningen af værftet spillet en ikke uvæsentlig rolle. Det er nok usandsynligt, at værftet skulle blive nedlagt, dels er værftet teknologisk set meget veludviklet, og dels har værftet end ikke i det dårlige år - 1977 - givet underskud. I regnskabet angives et overskud på 2 mill. kr. i 1977, medens overskuddet i f.eks. i de gode år 1973 og 1974 var på 14 mill. kr. Derimod var det og er det stadig ikke utcenkelig, at varierende dele af varftet braklagges for kortere eller længere tid for at fremtvinge gunstige akkumulationsbetingelser - det være sig ønskede indrømmelser fra værftsarbejderne eller fra staten.

\section{Afsluttende bemærkninger}

De fleste værfter er forholdsvis store arbejdspladser i de byer, hvor de findes. Deres dominerende stilling på især meltalarbejdernes lokale arbejdsmarked betyder, at svinninger i værfternes beskæftigelse fremkalder svingninger i det lokale arbejdsmarked, som får afgørende betydning for arbejdslønnens lokale svingninger for de beskæftigede værftsarbejdere. Den dominerende stilling for Lindø Værft og Nakskov Værft er ikke et særsyn, som det fremgår af tabel 11. Udfra tallenes størrelse i tabel 11 kan man imidlertid ikke slutte sig til, hvor dominerende en rolle de enkelte værfter spiller for det lokale arbejdsmarked; 
Tabel 11 Forholdet mellem værfternes beskæftigelse af metalarbejdere og de tilsvarende lokale afdelingers beskæftigede metalarbejdere. Værftsbeskæftigede i procent af afdelingsbeskæftigede.

\begin{tabular}{lccccc}
\hline & 1974 & 1975 & 1976 & 1977 & 1978 \\
Nakskov Værft & 70 & 72 & 68 & 63 & 63 \\
Odense/Lind $\varnothing$ Værft & 42 & 40 & 35 & 33 & 31 \\
Aalborg Værft & 30 & 31 & 26 & 24 & 25 \\
Frederikshavn Værft & 27 & 30 & 30 & 28 & 28 \\
Helsingør Værft & 63 & 62 & 56 & 51 & 46 \\
\hline
\end{tabular}

Kilde: Metalforbundets lønoversigt, diverse numre. Tallene for 1974-77 er gennemsnit af årets kvartaler; for 1978 er tallet kun baseret på januar kvartal.

det afhænger af det lokale arbejdsmarkeds sammensætning, som vi har vist det for Lind $\varnothing /$ Odense Værft og for Nakskov Værft.

Analysen viste, at beskæftigelsesfaldet i første omgang medførte reallønsfald og i anden omgang førte til en ændring af det eksisterende lønsystem, som for værftsarbejderne betød en forringelse, og som for værftskapitalen betød en tilpasning til det akkumulationsmønster, som nu var fremherskende.

Når udviklingen i den grad spiller initiativet over i kapitalistens hænder, er det vigtigt at inddrage ændringer i akkumulationsmønster, altså ændringer i profitproduktionsmetoderne. Eksempelvis sker der ændringer i lønsystemet i en helt anden retning på Frederikshavn Værft; her er der tale om en særdeles omfattende udvikling af arbejdets produktivkraft gennem usædvanlige store investeringer, som i 1975 - stik imod de aktionerende klubbers krav - førte til udvikling af et lønsystem, som mere ligner det lønsystem, som Lindøværftet afskaffede, end det, som Lindøværftet indførte.

Afgørende for udviklingen i værftsarbejdernes positioner er også den voksende industrielle reservearmé, som gør, at de lokale svingninger i arbejdsmarkedet kommer til at stå som formidler af den industrielle reservearmés samfundsmæssige tryk på arbejdslønnens generelle fald i krisen.

De tendenser og sammenhænge, som vi har vist for værftsindustrien, gælder uden tvivl for andre brancher og andre geografiske områder. Det der er specielt for værftsindustrien er, at værfterne er så dominerende og deres beskæftigelsesfald så betydende, at det er muligt forholdsvist let at efterspore udviklingen empirisk. Det vil straks være betydeligt vanskeligere for en række andre brancher og regioner; men det gør næppe de påviste udviklingssammenhænge til et specielt værtsfænomen. 


\section{TIDSSKRIFTET KURASJE}

\section{KURASJE 17}

148 sider. Kr. 35,00

Indhold:

Indkomstpolitik og kapitalakkumulation i Danmark af Bredsdorff, Brinch og Hansen.

Økonomisk krise, massearbejdsløshed og globalstyring af Semmler og Hoffmann.

Statsfunktioner og reproduktion af arbejdskraft af Finn Hansson.

Hvad skal vi med kapitallogikken? af Jens Henning Rasmussen.

Miljøanlæg og værdicirkulation af Erling Jelsøe.

\section{KURASJE 18}

168 sider. Kr. 45,00

Indhold:

Fagbevægelsens krisestrategi og den statslige indkomstpolitik af Bredsdorff, Holm og Søndergaard.

Kriseudviklingen i Danmark af Arne Kurdahl.

Den statslige arbejdsmarkedspolitik i krisen af Bo Elling Nielsen.

Fagbevægelsens lønpolitik af Erling Havn.

Typografarbejde af Andersson og Søndergaard.

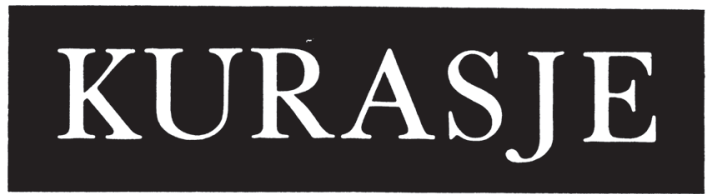

